\title{
Approach to the blade technology analysis of the Upper Palaeolithic site of “Tajos de Marchales” (Granada, Spain)
}

\author{
M. Alejandro García-Franco, Antonio Morgado \\ Department of Prehistory, University of Granada, Spain. \\ Email: García-Franco: alexandergf@hotmail.com; Morgado: morgado@ugr.es
}

\begin{abstract}
:
The study of the Upper Palaeolithic in the South of the Iberian Peninsula is usually addressed from a few stratigraphic sequences recognized in the region. We can say that the upper Palaeolithic in Andalusia is one of the worse known stages of regional prehistory. On the other hand, its development has just surpassed the description of the typological formal characterization. In some cases, recent contributions in the central region of the Baetic Mountain range, confined to the province of Granada, appeared during the last century.

In this sense, the present study has two objectives. On one hand, to present the site of the rockshelter 3 of the "tajos de Marchales" (Colomera, Granada, Spain), as a new Magdalenian site in the mountainous area of Sub-Baetic Andalusia.

On the other hand, through the application of diacritic analysis on cores, unretouched material and tools recognisable, we present the technological characterization of different chaîne opératoire from the production supported by the main idea of different typological objectives (domain of burins, scrapers and to a lesser extent with backed edge blades). We distinguish the different operational sequences aimed at the generation of the artefactual set. All of this will allow us to obtain a global comprehension of the lithic assemblages from the site, and to define the beginning of its chaîne opératoire. The work presents and discusses the distinctive traits of the different technical elements, focused on laminar production (blades and bladelets) and knapping methods.
\end{abstract}

Keywords: technology; debitage; diacritical schemes; Upper Paleolithic; Subbaetic

\section{Introduction}

The Upper Paleolithic of Andalusia is one of the periods of the regional prehistory which is being intensively researched in different sociocultural aspects (evolution, lifestyles, and technology). Despite this, the analysis of the methods of debitage for the elaboration of lithic instrumental is scarce. The material culture has been usually characterized from traditional, typological and formal descriptions, without a paleoethnographic approximation defined by its own technical frame and its cultural identity (Aura et al. 2010a; Cortés 2007a; 2010; Fortea 1986; Fullola et al. 2005; Ripoll 1988; Vallespí 1995). This objective must be approached from a dynamic comprehension of the static reality of the archeological objects,

Published by the School of History, Classics and Archaeology, University of Edinburgh ISSN: 2055-0472. URL: http://journals.ed.ac.uk/lithicstudies/

This work is licensed under a Creative Commons Attribution 2.5 UK: Scotland License. 
which orientates the contribution of our work. The Mediterranean area results in controversy due to previous proposals referred to the particular genesis of the Upper Paleolithic (Cacho 1980; 1982; Vega Toscano 2005).

Our objective is the lithic-technological definition of a new outdoors deposit belonging to the Magdalenian in the Iberian Mediterranean of the Subbaetic of Granada. There are many technological indications that allow us to assign the lithic assemblage_from Tajo de Marchales to the technical framework of the Archaic Magdalenian (García-Franco \& Morgado 2016: 719). Up until now, there have been some contributions about its techno-typological study which has allowed a first chrono-cultural ascription based on the assemblage of artifacts with debitage (García-Franco \& Morgado 2016: 7-19). In light of this, we will carry out a brief review on the state of the final Upper Paleolithic in the region aiming to delve into the technical framework of "Tajo de Marchales", which will enable us to establish a plain argument about it.

The earliest chronology from the Upper Paleolithic at the south of the Iberian Peninsula comes from a chrono-sequential fixation of archaeological Aurignacian layers in Bajondillo $(\mathrm{Bj} / 13-11)$, and there have been proposals in Zafarraya about a Proto-Aurignacian period (Barroso \& Lumley 2006; Cortés 2007a,). The typological elements found at different deposits are enough to state Gravettian evidence at the south of the Peninsula (Aura et al. 2010a; Cantalejo et al. 2003; 2006). This can be confirmed at Nerja and Bajondillo and possibly, at Higueral de Valleja, shelters of the Humo and La Pileta complex, all of them chronologically defined between c. 26000-21000 B.P. after c. 21000 B.P, the Solutrean develops at the Mediterranean sequence, being the best represented in Andalusia (Ambrosio, Nerja, Bajondillo, Abrigo 6-Humo, Higueral de Valleja, Cueva de los Ojos o Peña de la grieta), the majority of which are still under study or presented in form of previews (Giles et al. 2000, Ferrer et al. 2005). These are frequently characterized through an erosive discontinuity along of 22000-20000 cal. B.P. (Aura 1995; 2007). The sequence of the Parpalló cave (Valencia) is the basic reference for the transition from Solutrean MagdalenianBadegulian Mediterranean of Valencia (Aura 2007; Fullola 1979;Pericot 1942; Villaverde et al. 1998;) without having any presence in Andalusia.

So far, there is no clear evidence in the archaeological record of occupations between 16,000 and 12,500 B.P. In the case of the Nerja cave, the Upper Magdalenian levels (Sala del Vestíbulo NM-7) are over the Solutrean levels (Sala Vestíbulo NM-8), due to an erosive contact (Aura \& Pérez 1992).

It is unknown, at least, up until now, what happened during the initial phases of the Magdalenian in the region. This isn't the case with the Final Upper Magdalenian EpiPaleolithic, represented in the levels of transitions Final Upper Pleistocene-Holocene in the Nerja cave, which offers, with difference, the best contrasted series in extension, depth, chronological contextualization, artistic, etc. at the south of the Iberian Peninsula for the Final Upper Pleistocene and Ancient Holocene (Aura,1995; Aura et al. 1998; Jordá 1986; Jordá et al. 1990; Pellicer \& Morales, 1995; Pellicer \& Acosta 1997).

The lithic industry of Nerja states, in comparison with earlier phases, a drastic reduction of typometrical modules, and at the same time adds, as innovative elements, materials like scalene triangles, harpoons and rectilinear hooks (Aura \& Perez 1998), while in the manufacture of projectile points over animal hard materials, the election of deer antlers over the bone predominates (Aura 1986; Aura et al. 1998; Jordá 1987). The industry associated to these deposits keeps the microlaminar pattern outlined for the Magdalenian, incorporating some scalene triangles and points with curved back, but increasing the production of flakes, in detriment of the bladelets.

The different levels of the Bajondillo cave (Málaga), (NB1, NB10a and B/6, 7, 8), show a strong presence of Upper Paleolithic. Of our best interest are the levels B/6, 7, 8, which 
show, at typological levels, a tendency of the scrapers to set up in thick shapes, attribute that may be related to the bladelets production, and also show the predominant burins over truncations along with the preferential elaboration of backed tools. The typological indexes are characterized from the B/10 inside a Solutrean-Gravettian frame (Cortés 2007). El Pirulejo (Priego de Córdoba) shows Magdalenian characteristics in its layers (P4D, P/4, P/3, P/2), and, taking into account the characteristic statistical parameters of this attribution, we will highlight the presence, for the first time in the series, of deep pointed backed tools (classifiable as microgravettes) in the most recent deposit, along with the rare presence of the bone industry, and the progressive disappearance of the pointed flakes with archaic similar (Cortes 2007b; 2008; 2010).

In the Subbaetic area, we find the Solutrean-Gravettian deposit of "Pantano de Cubillas" of which typological index, showed by the present analysis, suggested to the authors the cultural ascription of the industry of this Solutrean deposit (Toro et al. 1979; 1980).

According to several authors (Aura 1988; 1989; 1995; 1997; Aura \& Pérez 1992; Aura et al. 1998; Fortea 1973; 1985; Villaverde et al. 1998; 1999; 2008), the cultural manifestations developed during the first phases of the late glacial in the central sector, and the southern peninsular Mediterranean, could be sequenced in the 1) Archaic Mediterrean Magdaleniean Badegulian "tipo Parpalló” and 2) Archaic Magdalenian of laminar knapping. The temporal proximity between the Iberian Epi-Solutrean and the MAM-A defined by Cortes (2007; 2008), or the existent techno-typological differences between both of them, do not allow the explanation of the latter as an evolution form the Late Evolved Magdalenian, hypothesis only supported by the similarities between some elements of the portable art and the bone industry (Aura 1995; Villaverde \& Martínez 1995). The Epi-Solutrean or Iberian Evolved Solutrean (Aura \& Jordá 2012) would be contemporary to the Badegoulian development. This has allowed for questioning the chronological proposal for the Late Iberian Evolved Solutrean and the Late Mediterranean Magdalenian (Bosseelin 2000), although it does not overlap with the chronological totality of the Cantabrian Lower Magdalenian and the SE of France (Aura 1989). Apart from the "Parpalló", this type of industry has not been found in any Peninsular Mediterranean deposit. We can find the nearest parallels in the Late Portuguese Magdalenian (Cabeço de Porto Marinho-Cerrado Novo), which has absolute dates of c. 16500-14000 B.P. (Zilhão 1997). This can show us, indirectly, the probable chronological location in the Late Glacial of the Late Mediterranean Magdalenian.

Subsequently, after analyzing the assemblage of Magdalenian facies from Western Europe, some authors' (Bosselin \& Djindjian 1988; Bosselin 2000) exhibit the existence of flake industries predominantly blades and the manufacture of tools over bladelets (30-70\%) in c. 15000. B.P. named as facies M2 (Córtes 2007a; 2008), known as "Late Magdalenian of laminar debitage” (Cortés 2002). In this regard, J. Fortea (Aura 1995: 17) pointed the potential existence of records with these parameters in the Peninsular Mediterranean area; assemblages that may represent the beginning of techno-typological attributes that would be developed during the Upper Mediterranean-Magdalenian (Aura 1997).

Therefore, given that the laminar component of this stage of the Upper Paleolithic is part of the technological process of human groups, the analysis of cores and sculpt products are transformed into the basic elements to state the methods and procedures of these huntergatherer bands at the south of the Iberian Peninsula. We approach the analysis from a methodological perspective that allows the establishment of the debitage dynamic from the diacritic lecture of the archaeological material (Baena \& Cuartero 2006; Castañeda 2011; 2015; De la Peña 2009; 2011; 2012; Inizan \& Roche 1980; Inizan et al. 1999: 126; Pelegrin 1990; 1991), an under-explored and systematized perspective for the assemblages from the Upper Mediterranean Paleolithic. The technical analysis of the cores, products and sculpt remains, along with the experimentation, have allowed and integral dynamic vision. The cores 
analysis is important in the definition of the process of transformation of the raw material, due to the degree of normalization and the management in the concepts of the economy of raw materials and sculpts (Perlès 1980). There are few studies in Andalucía about the methods of laminar debitage from the Upper Paleolithic based on cores and laminar blanks. Therefore, this paper contributes with reference elements for the comprehension of the aforementioned technology of the hunter-gatherers of the Iberian Peninsula.

\subsection{Analysis Methodology}

The analysis of lithic artifacts has been traditionally made from morphologic perspectives, i.e. from its static reality. This analytical approach, quite popular during a large part of the 20th century in the western historiography, ended thanks to the change that represented its comprehension as products from an elaboration process and use. This change of perspective opens up from several paths, but fundamentally from an anthropological perspective (Bordes 1947; 1950; 1961), as a reaction to the excessive descriptive computation of the lithic artifacts (Binford \& Binford 1996; 1969; Carbonell et al. 1992; Laplace 1972; Sackett 1966), and in favor of a comprehension of these as elements from a process of acquisition, transformation, use, maintenance and recycling, taking the concept of chaîne opératoire as a methodological tool (Cahen et al. 1980; Inizan \& Roche 1980: 56; Pérles 1991; Pelegrin 1990; 1991). This perspective of the macroscopic analysis of a lithic set (Baena \& Cuartero 2006; Castañeda 2011; 2015; De la Peña 2009; 2011; 2012; Garanger 2002; Pelegrin 1990; Pelegrin 2002; Julien 2002) implied a comprehension of the methods and techniques of knnapping through the refitting, the diacritic reading, and the archaeological experimentation. The latter plays an important role as element of comprehension (Pelegrin 1991). Thereby, overcoming the sole typological description, this lecture allows us to infer strategies, behaviors, and tacit knowledge in the elaboration of lithic artifacts (Baena \& Cuartero 2006).

The basic principles that rules the different types of fractures, which at the same time are placed in a series of attributes and features, are the ones used in the process of analysis and explanation of the chaîne opératoire of transformation, established by the analysis of the objects through the so-called "diacritic readings" (Baena \& Cuartero 2006: 142). The final objective is the technological characterization that enables the comprehension of the archaeological lithic collections from a global perspective, besides giving coverage to the cultural and socio-economic knowledge of the prehistoric lifestyles. In this regard, the diacritic reading turns out in a methodological tool which enables the characterization of different methods of debitage. This kind of lecture expressed in a "diacritical scheme", which is understood as:

"Simple graphic representation of time-space character of the composition of a prehistoric lithic object, that is to say, a visual expression of the essential information in its stigmas, allowing fixing the chronology of the technical gestures," (Davois 1976: 195).

The analogic simulation of the process of debitage in present times, and the use of comparative models, has endowed a new dimension to the studies of technological analysis (Baena \& Cuartero 2006: 147; Pelegrin 1991). It is possible to establish the manufacture and the elaboration process in a crono-sequential way, through the arrangement of the negative removals (Inizan et al. 1999: 126). The importance of being able to identify those technical aspects which make possible the orientation of the extractions, or comprehends the implicit traits in the superposition of these ones, help us to reconstruct in an objective way the series that are presented in the archaeological objects and also to visualize possible patterns or technical guidelines. In this way, we establish a comparison between demeanors, and not simply between typologies. The proper technological lecture needs the analytic observation of 
the remains and its attributes, as well as the capability to perform its experimental reproduction, and the comparison for both. The analysis of the diacritical reading is always proposed from a macroscopic scale obviating the microscopic analysis, due to methodological reasons (Baena \& Cuartero 2006).

We start with the idea that the basic objective of the technological analysis is not solely confined to the recognition and the comprehension of the individuality of the object, its biography, but instead it is included in an analysis that originates on this singularity and establish the patterns of the sets of archaeological evidences. Thus, it seeks to know the approximately lineal character of the technological process implicit in the assemblage, the possible changes in the technical objectives, the particular strategies, reuses and recycling, etc., in such a way that it is recognized the real cultural meaning of the analyzed products (Baena \& Cuartero 2006; Julien 2002; Pelegrin 1990).

The application of these criteria for the determination of series of the archaeological assemblages is performed through a graphic analysis of the technical lectures of diacritic schemes over each piece (Dauvois 1976; Inizan et al. 1999).

Thereby, we have been able to study the recurrent technological characteristics of the assemblage and the particularities of each object. In the last instance, the displayed conclusions are the result of an interpretive explanation over the technological characterization of the assemblage of Tajos de Marchales. The interpretation of the diacritical schemes enables the discrimination of the predetermined objects in relation to the predeterminers i.e. that makes possible the discrimination between traits or collective demeanors, versus individual or isolated aspects.

It's important to highlight that this methodological tool enables to make inferences about the degree of technological homogeneity of the analyzed assemblage, in such a way that establish a solid interpretative base for the study of the productive system at its whole (Böeda 1990).

The criteria followed for the diacritical reading are the same mentioned by Baena \& Cuartero (2006), and he ones that we highlight are: a) The direction, b) The superposition or ordination of the negatives, and c) The ordination of the negatives among different surfaces.

The analysis of the laminar cores was made under the criteria of the extraction (technique), the series and sequences of debitage. In the cores it was identified the following:

- Striking platform: This is the one from which the extraction of the core was performed.

- Sideward preparation: As its name suggests, intended for the lateral conformation of the core with the purpose of seeking ideal platforms of debitage

- Debitage platform: It is the sequence that would be determined in the debitage, and the one from which the desired chaîne opératoire products were extracted.

With the aim of comprehending the debitage methods of the laminar cores, we analyzed the laminar material without retouch within the collection. In this regard, we established groups in relation to the presence of negatives removals on its dorsal face and the cortical degree. We defined five groups, the $1^{\text {st }}$ group) consists of pieces which present a cortical degree over $50 \%$ and which do not present a bigger number of dorsal negatives removals. The $2^{\text {nd }}$ group) consists of pieces which present a cortical degree between $30 \%$ and $40 \%$ on their surface with the presence of one or two negatives on its dorsal face. The $3^{\text {rd }}$ group) consists of pieces with a cortical degree fewer than $30 \%$ and the presence of 4 to 6 negatives removals on their dorsal face and the absence of cortex. The $4^{\text {th }}$ group) is characterized by laminar pieces of regularization of the debitage. The $5^{\text {th }}$ group) consists of blades of internal debitage. Mostly, these groups can be understood as cortex removal ( $4^{\text {th }}$ and $5^{\text {th }}$ groups), preliminary flaking ( $3^{\text {rd }}$ group), and internal debitage ( $1^{\text {st }}$ and $2^{\text {nd }}$ group), although for the descriptions we 
will use the five classifications described above, with the aim of describe the study material in a better way.

\subsection{The lithic assemblage from Abrigo 3 de Tajo de Marchales}

The deposit is located at the south part of the Iberian Peninsula (Figure 1), inside the Baetic system, specifically, in the domain of the Central Subbaetic Granedian. It is located within the municipality of Colomera, at Tajo de Marchales, at the northeastern side of the province of Granada.

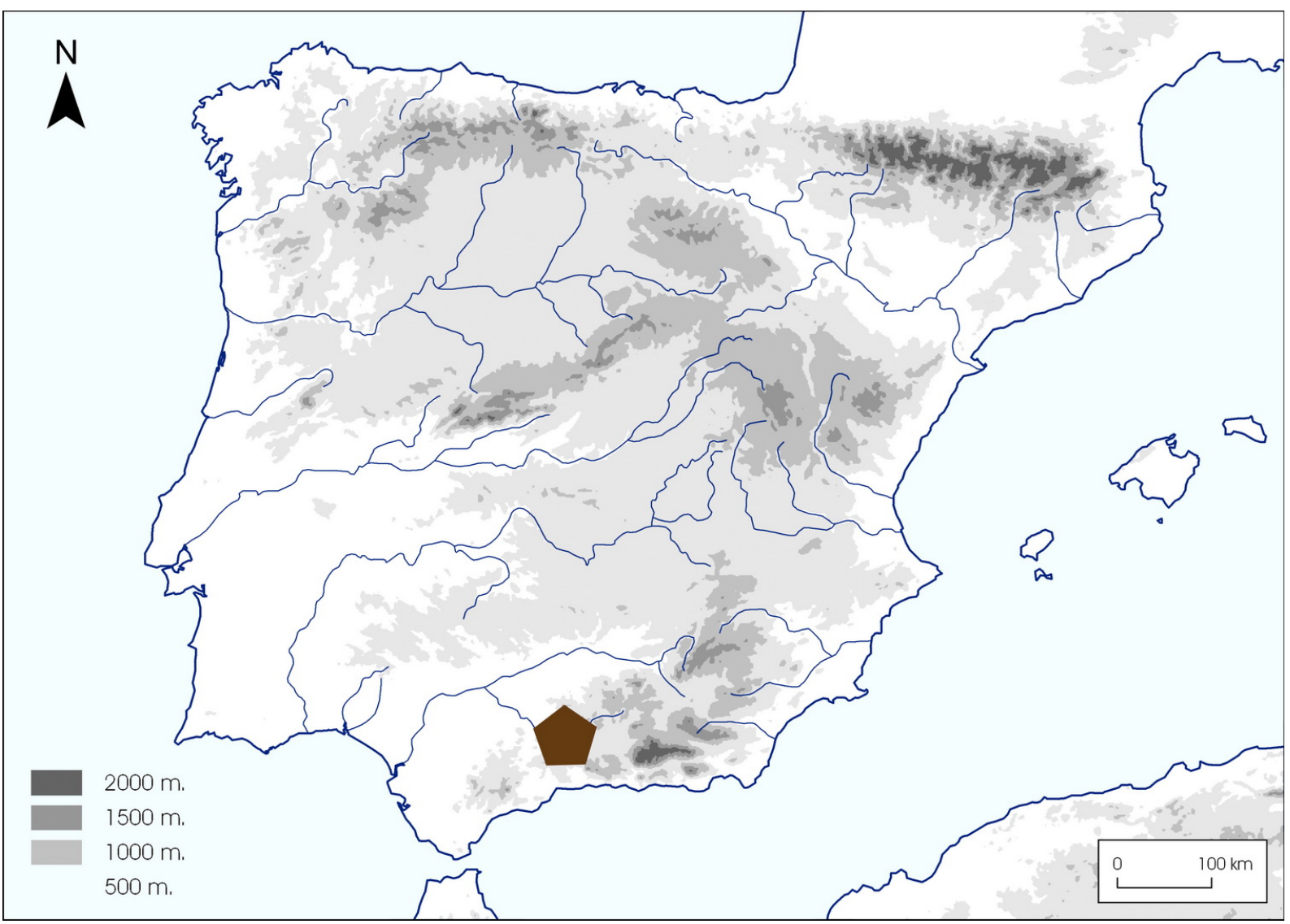

Figure 1. Location of Tajo de Marchales.

This natural spot was previously reported in the Catalogo General del Patrimonio Histórico Andaluz, due to the presence of shelters with rock art, being consequently protected by the maximum instance, BOE $\mathrm{n}^{\circ} 155$ at the 29 of June of 1985.

The stone block which protects Abrigo 3, has slowly displaced due to the geo-dynamic and erosive action that works over the Cretaceous lands of ritmias margosas and pelagic limestone, thus favoring the inclination of the slope. Abrigo 3 is confined between the bases of the tajos ("steep cliff") at its headboard and the ravine of the Hachaz. This ravine descends from North to Southeast intercepting the lower limit of the skirt of this terrace. This mount is conformed of volcanic rocks from the Jurassic period at Domerian-Aalenian levels. The encounter of the margo-limestone with the ravine may be the cause of the displacement due to the erosion produced at the base during the moments of depletion, dragging the margas of lower hardness of the slope with volcanic precedence, and favoring the sliding of margas.

The assemblage so far known as "Abrigo 3 de Marchales" corresponds with some surface pickups as a consequence of the destruction of the most recent level of the shelter, and of the change that occurred at the end of the $20^{\text {th }}$ century in the Mediterranean understory that 
was replaced with olive grove, only embracing one level and the roof of the second stratigraphic package of $30 \mathrm{~cm}$ of thickness. Two main zones for the recollection of material were erected (Figure 2), both unaltered, because of the emergency action that was implemented. The first of these areas occupies an area of $6 \mathrm{~m}^{2}$ and it is exclusively located at the base of Abrigo 3 de Tajo de Marchales. From there comes the biggest part of the lithic material since it is an area with less alterations and has a strong presence of archeological material. In the coming years, this area will be subject of probing with the intention of recovering and defining the deposit stratigraphically. The second one occupies an area of 10 $\mathrm{m}^{2}$, and we found a loss of archeological material around its edge with olive trees and around its limit with a slope.

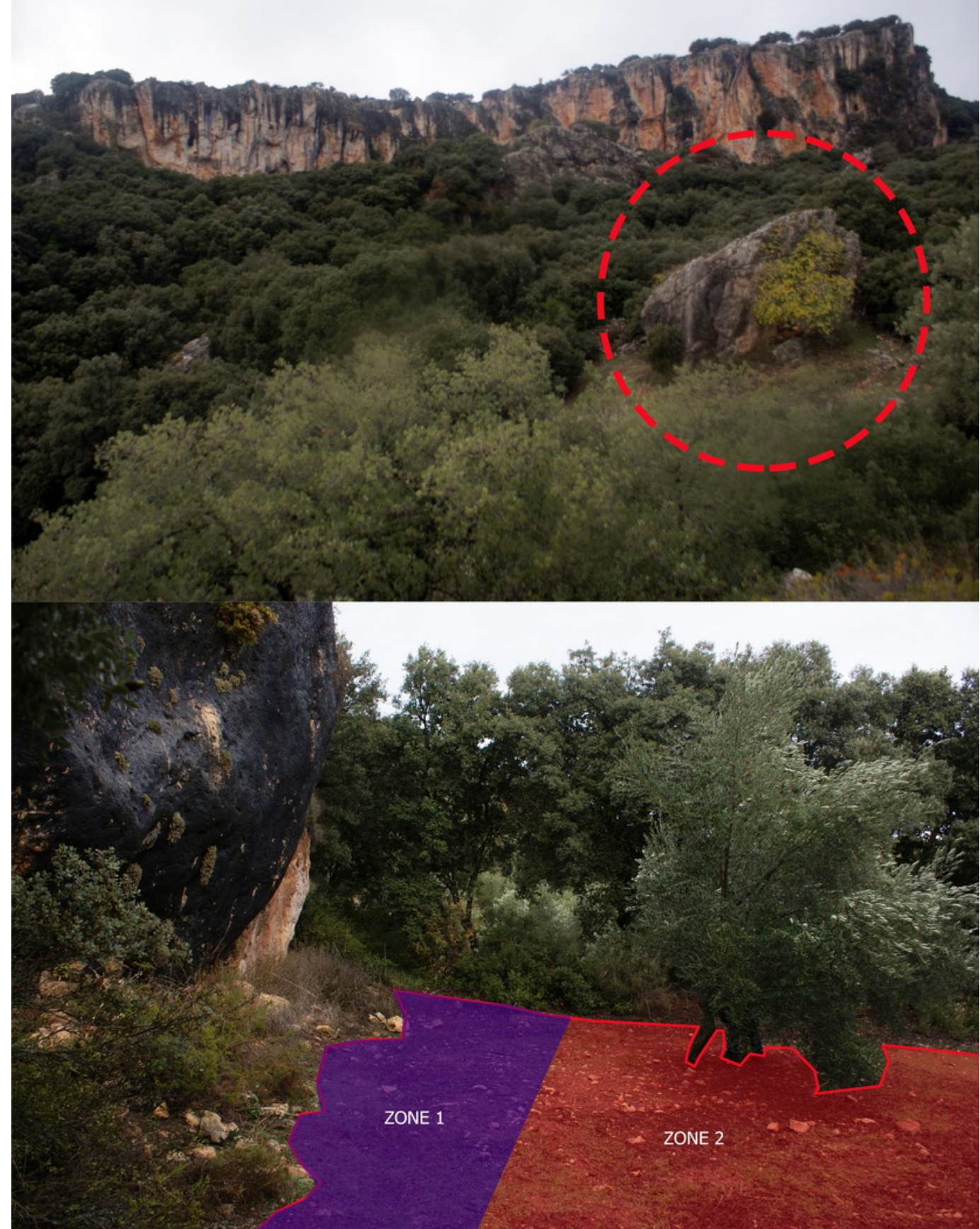

Figure 2. Location by zones of recovery of the archaeological materials. 
In this regard, we are cautious with the establishment of a sequential definition, which should be corroborated in future interventions. Despite that, the known archaeological assemblage has allowed us to reaffirm the formal characteristics, which along with the comparison of other deposits, place it between the assemblages from the recent Upper Paleolithic, and especially the Ancient Mediterranean Magdalenian. This cultural ascription was made while having in mind: the characteristic types of burins, its proportion with the rest of typological groups, and the incidence of backed tools, as well as the presence of backed points with the absence of geometric elements, immediately after the Badegoulian defined in Parpalló and other deposits in this area (Aura 1995; Aura et al. 2012). Incidentally, the typometry and the low incident of the backed microbladelets place it away from the tendency of the Upper Magdalenian.

\section{Typological analysis}

The classification of the assemblage of cores and the products of debitage from Abrigo 3 of the setting of Tajo de Marchales has been based on the morpho-typological systematics used for the Upper Paleolithic of the Ancient European Prehistory (Sonneville-Bordes \& Perrot 1954-56; Moure Romanillo 1970; Brezillon 1971; Fortea 1973; Demars \& Laurent 1992; Merino 1994; Benito del Rey \& Benito Álvarez 1998). The recovered assemblage has provided a lithic repertoire which expands the knowledge of the Upper Paleolithic from the province of Granada (Aura et al. 2006; 2010; Aura 1995, Cortés 2003; 2008; Cantalejo et al. 2006; Ripoll 1988;), although, so far, we do not have a sequence of the shelter, because such assemblage comes from superficial gatherings belonging to the removal of the last occupational levels.

The main categories of the assemblages of debitage artifacts located at this place are constituted by a large quantity of items. There are 832 pieces representing the whole lithic material; the complete count of the pieces (Figure 3) includes debris and chunks.

We divide the material in four groups. Products of debitage like flakes, laminar flakes and blades compose the first one with 347 representing the $41.70 \%$ of the collection. Cores, which represent a $4.92 \%$ of the collection, with 41 pieces, integrate the second one. The third and fourth ones are conformed by debris and chunks representing $28.12 \%$ and $25.24 \%$ of the collection, with 234 and 210 pieces, respectively.
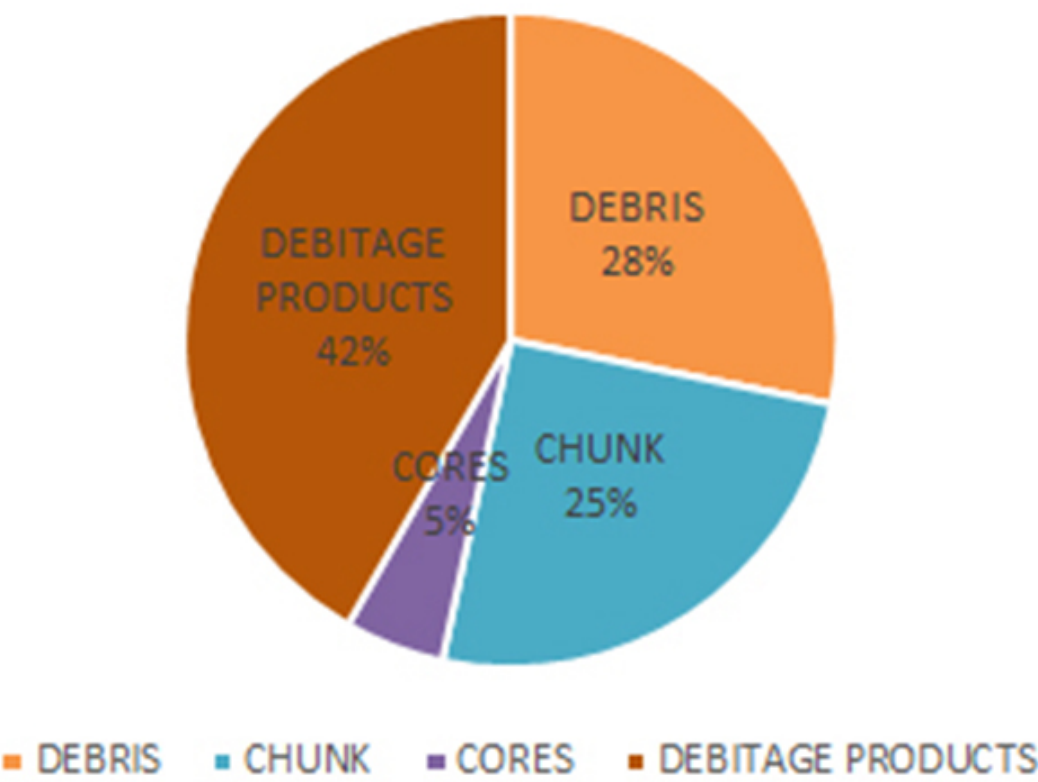

Figure 3. Lithic assemblage that conforms the collection of Tajo de Marchales. 
120 flakes, 102 laminar flakes, and 125 blades, making 347 pieces in total, integrate the material product of the debitage. In general, on the analysis of the butts, we observe that among the total of pieces with butt's presence, the plain, punctiform and diehedral types predominate (Figure 4). Taking the $59.27 \%$ of pieces with butt presence, 88 pieces belong to internal debitage, representing a $38.26 \%$ of the material with butt presence, and $25.36 \%$ of the total of products of debitage. The preliminary flaking material ascends to 114 pieces; the preliminary flaking material with butt presence represents $49.26 \%$ of the total of pieces with butt presence, and $32.85 \%$ of the total of the product of debitage. With 22 pieces of cortex removal and butts presence, $9.26 \%$ come from butt presence material, and $6.34 \%$ from the total of products of debitage.

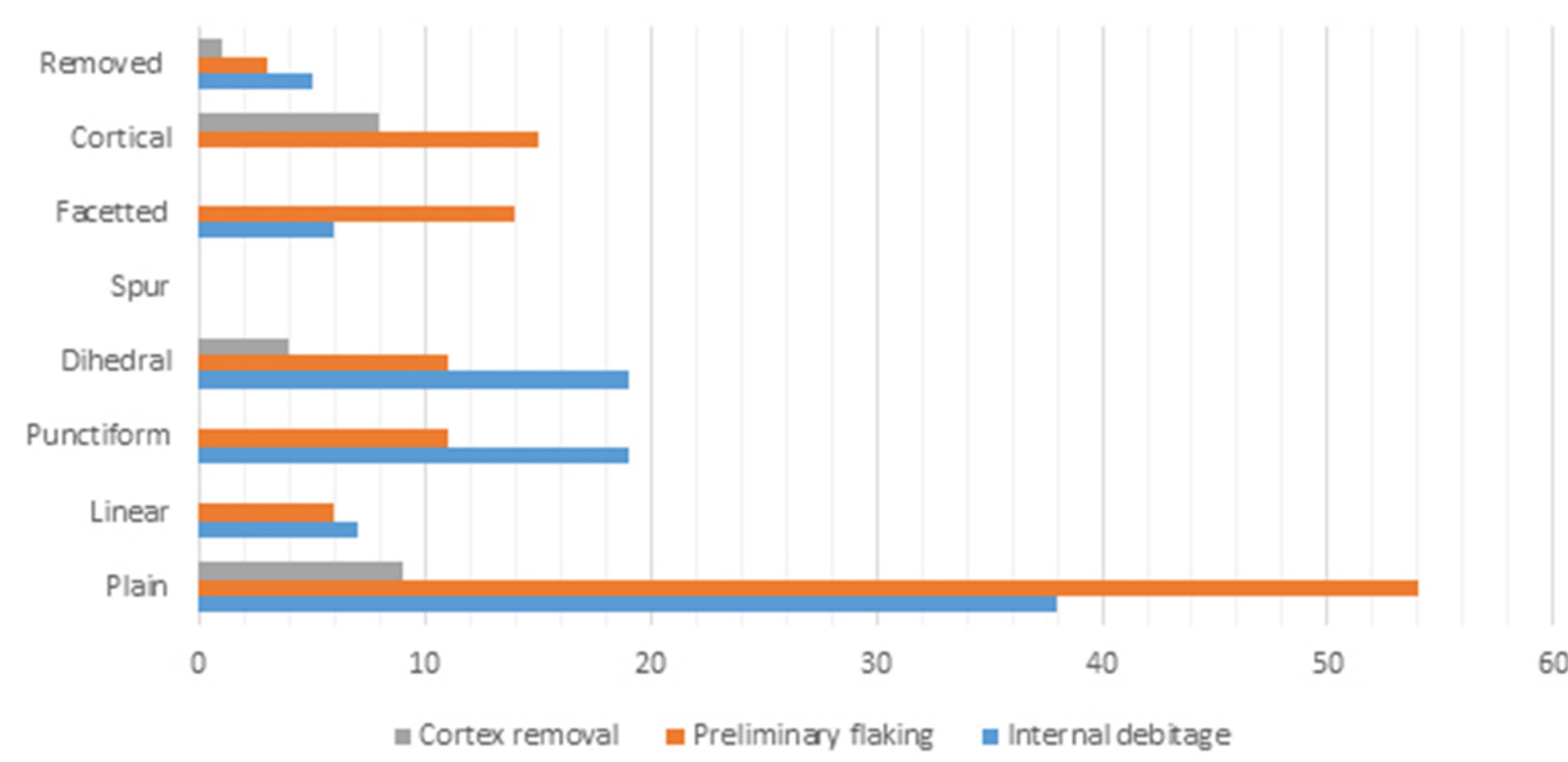

Figure 4. Corresponding overall percentages from butts.

Taking the total of products of debitage (347), 256 pieces do not have retouch, among which 137 have been used to obtain the elongation index. The selected pieces for the elaboration of the indexes carried the discrimination from part of this assemblage, and, todo do this,. complete pieces were selected, without the presence of retouch, with the aim of observing the demeanor of the laminar debitage in the collection, and that can be observed in Figure 5. The table depicted in Figure 5, is based on dispersion graphics obtained from the elongation index. The analysis transforms the data to Cartesian coordinates in order to observe zones with high or low dispersion or concentration. The diagram changes into a histogram that offers a quantitative image of the real distribution of the assemblage. This histogram is obtained through the subdivision of the Cartesian diagram in many sectors, having as element the relation length-width in an arbitrary mode, corresponding to the admitted dimensions by various pre-historians (Tixier, Laplace, Leroi Gourhan) as B. Bagolini says (1968). The clear presence of a laminar tendency in the assemblage is visible, and its concentration in blades and bladelets confirm it as a material from the Final Upper Paleolithic.

\subsection{Material with retouch presence.}

We found 91 items among the total of materials which are product of debitage with retouch presence, among which $10.98 \%$ are scrapers, burins (20.87\%), drillers (4.29\%), backed tools (3.45\%), truncations (2.19\%), shoulders and denticulates (18.68\%), and 
ultimately miscellaneous materials with retouch presence (39.44\%), flakes and predominantly blades (Figure 6).

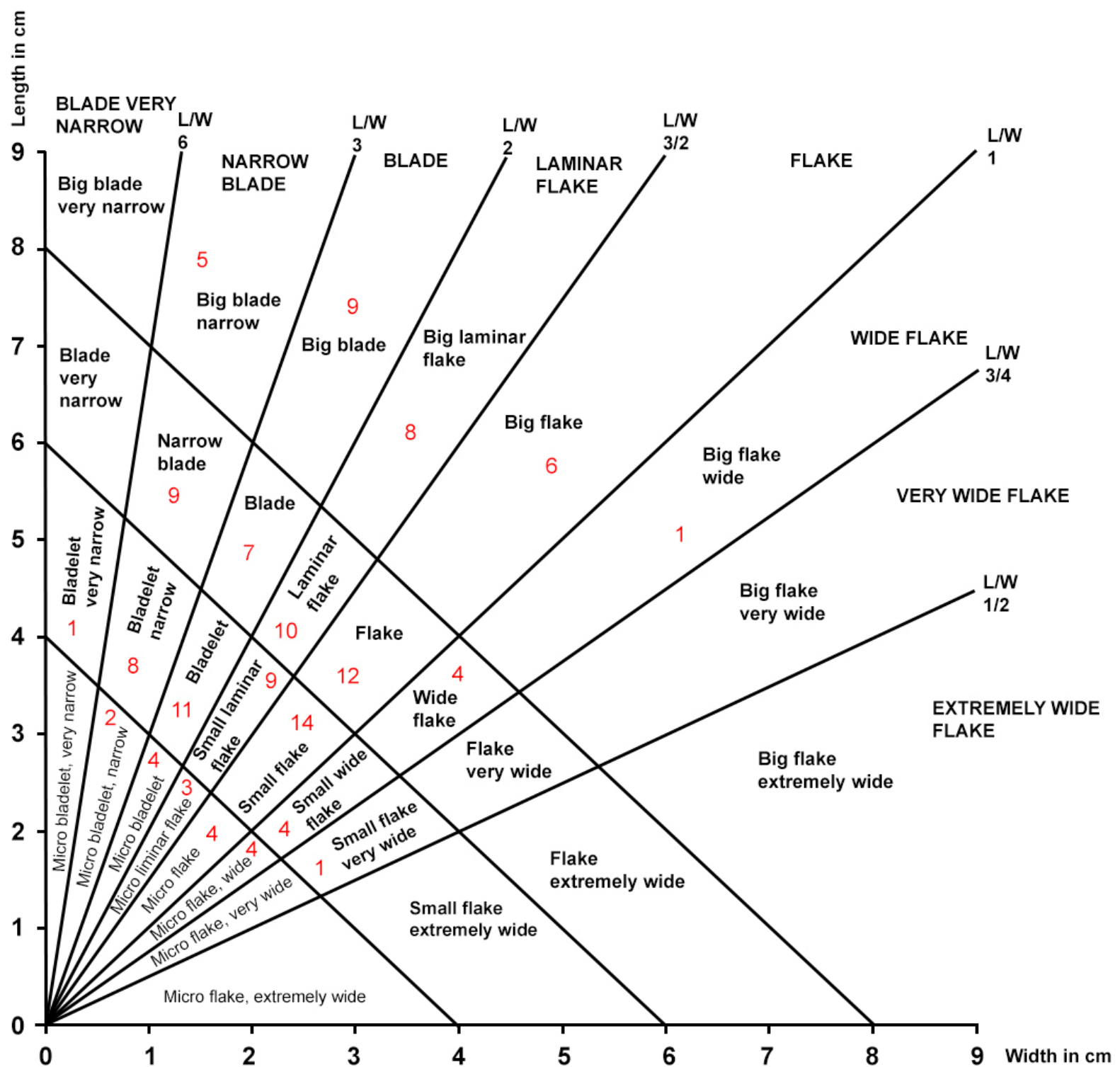

Figure 5. Laminar representation of the lithic assemblage from Tajo de Marchales.

We have not been into account the group conformed by the burins for the description of the retouch; therefore, the following tables and percentages were done without such group. However, for the general index of the material able to be typologically assigned, we have accounted the burins as part of the retouch material. This is mainly because the preparation of burins is a "special technique of retouch" (Inizan et al. 1999: 133) It is defined as the "action of making burins facets" (Inizan et al. 1999: 84). Therefore, we have decided to create a special section to describe the special retouches, like the burin spall case.

The total items used for the general description of the retouch ascend to 72 (excluding burins) corresponding to $20.74 \%$ of total of products of debitage. Said percentage divided between laminar flakes (26.02\%), flakes (36.98\%), and blades that represent 35.61\%.

The retouched material from pieces of internal debitage represents $48.61 \%$ of total of retouched material and $10.08 \%$ of total of the products of debitage. The preliminary flaking material represents $43.05 \%$ of total of retouched material and $8.93 \%$ of total of the product of 
debitage. Ultimately, the cortex removal material represents $8.33 \%$ of total of retouced pieces and $1.72 \%$ of total of the products of debitage.

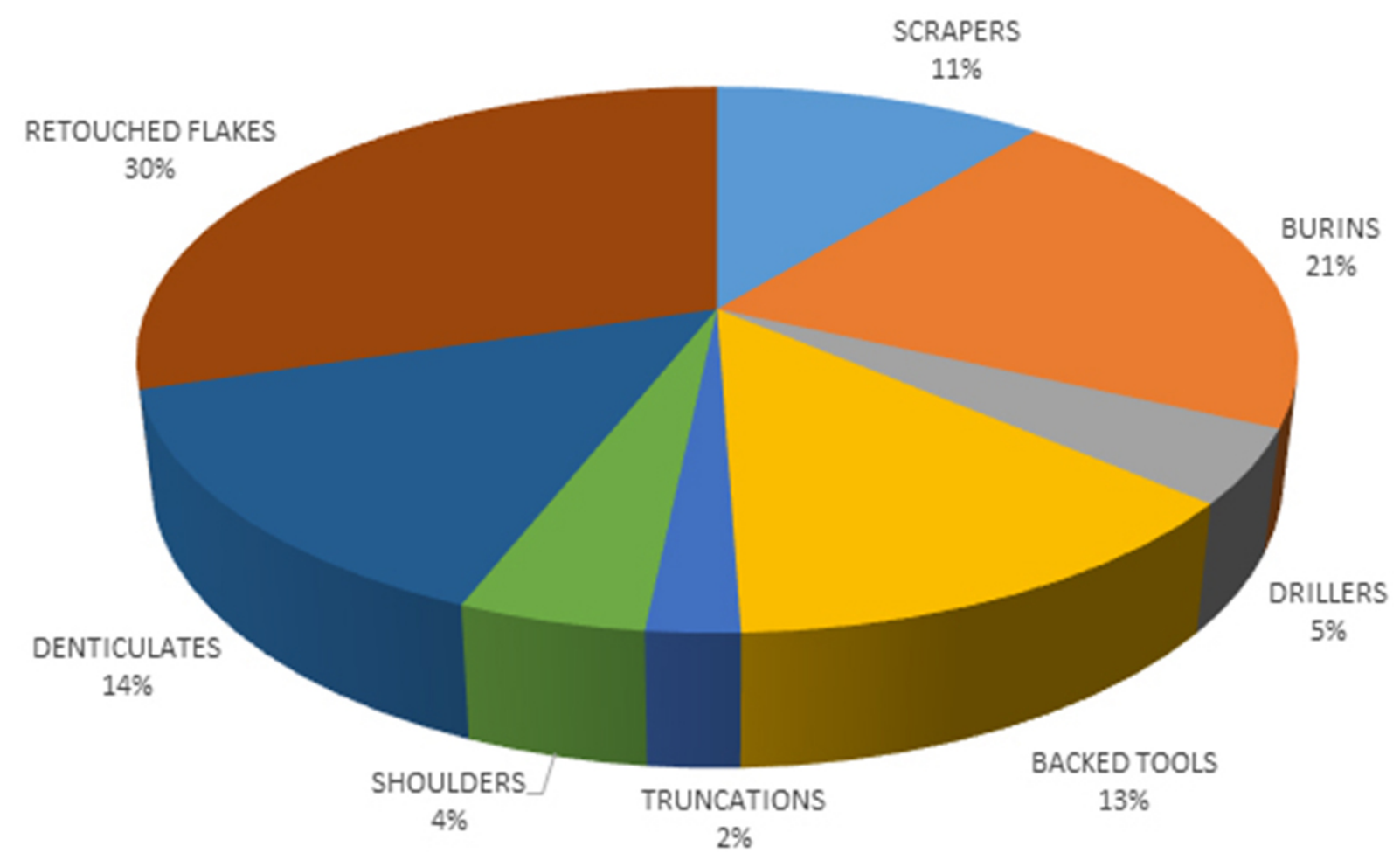

Figure 6. Total retouched material from the assemblage.

It can be observed from the different locations of retouch that the distal position represents $30.55 \%$ of the retouched material and $6.34 \%$ of the product of debitage. The mesial location represents $2.77 \%$ of the retouched material and $0.57 \%$ of the material product of the debitage. The proximal position represents $6.94 \%$ of the retouched material and $1.44 \%$ of the material product of the debitage. We have on its right location $26.38 \%$ of the retouched material and $5.47 \%$ of the material product of the debitage. On its left location we have a $33.33 \%$ of representation of the retouched material and $6.91 \%$ of the material product of the debitage, and we do not have a representation on its basal location (Figure 7).

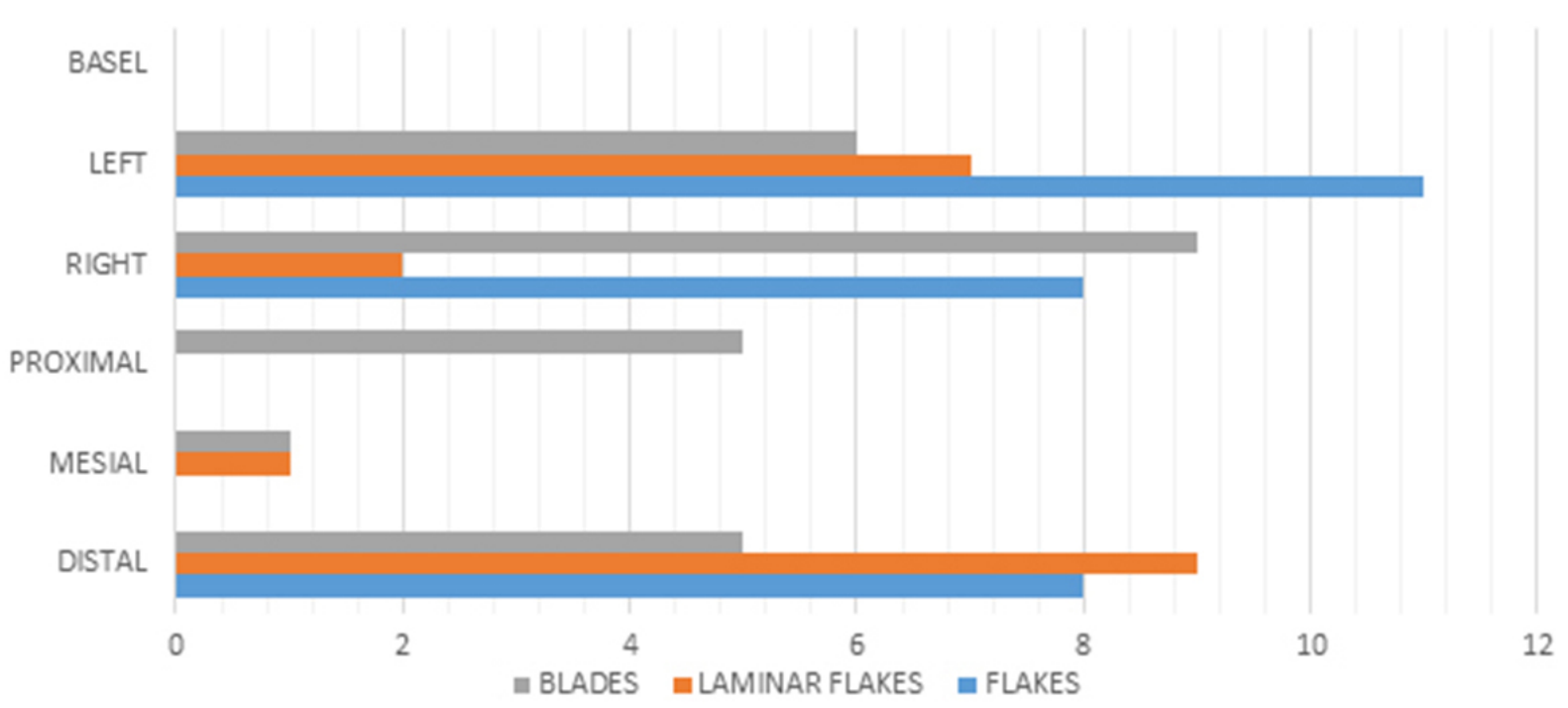

Figure 7. Location of the retouch. 
According to the direction, the direct (el directo), represents $72.22 \%$ of the total of retouched pieces, and $14.98 \%$ of the total of products of debitage. The inversed and crossed represents respectively $13.88 \%$ of the total of retouched pieces and $2.88 \%$ of the total of the products of debitage (Figure 8).

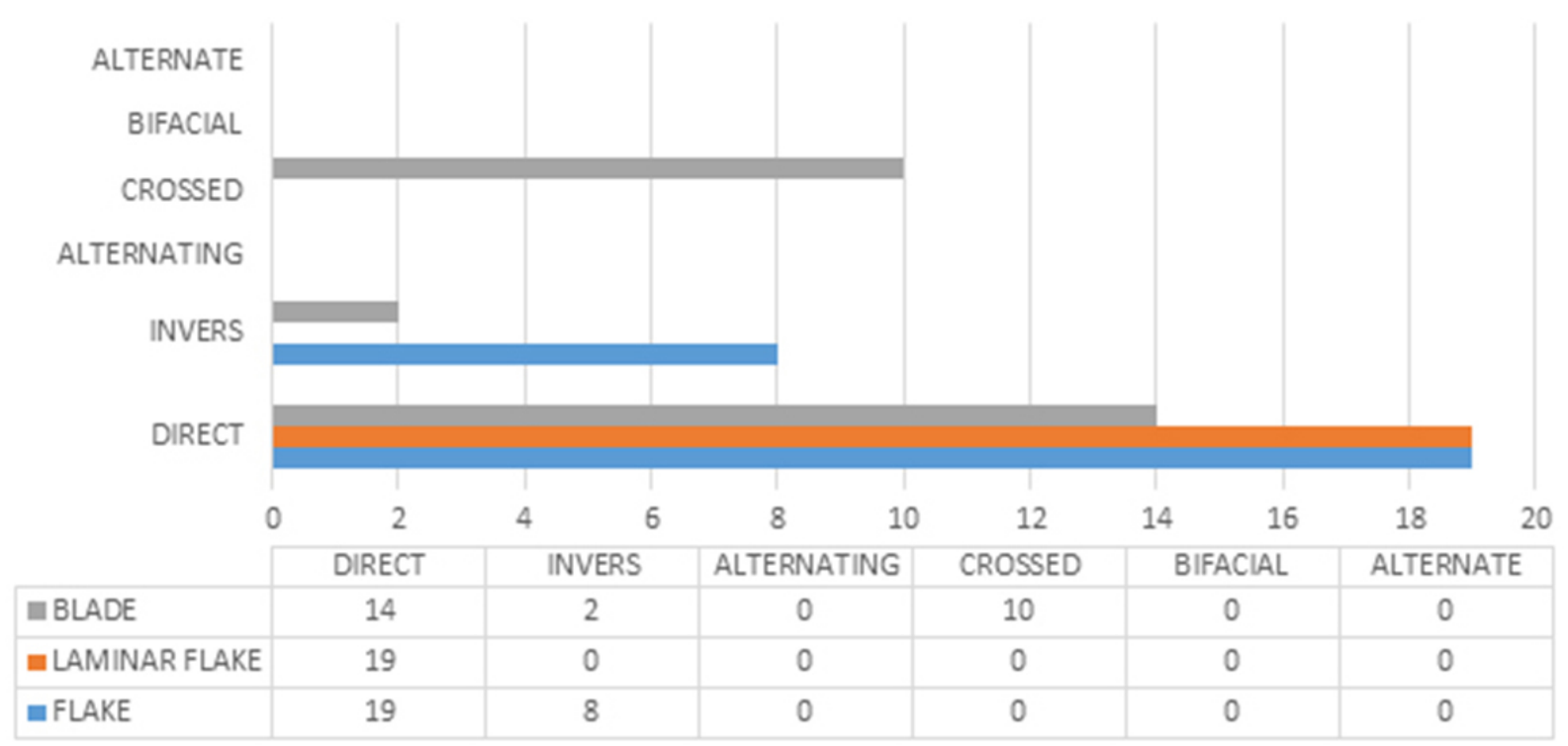

Figure 8. Distribution according to the different types of direction in the retouch.

The retouch with rectilinear and concave delineation represents $2.77 \%$ of the retouched material and $0.57 \%$ of the material product of the debitage. The convex delineation represents $22.22 \%$ of the retouched material and $4.61 \%$ of the products of debitage. The denticulates represent $18.05 \%$ of the retouched material and $3.74 \%$ of the total of the products of debitage. The regular delineation does not represent a percentage, but the irregular delineation represents $34.72 \%$ of the retouched material and $7.20 \%$ of the total of the products of debitage. The notch represents $1.38 \%$ of the retouched material and $0.28 \%$ of the total of the products of debitage. The shoulders represent $5.55 \%$ of the retouched material and $1.15 \%$ of the total of the products of debitage. The stepped represents $1.38 \%$ of the retouched material and a $0.28 \%$ of the total of the products of debitage. The delineation by tang does not represent a percentage, but the delineation by tongue represents $11.11 \%$ of the retouched material and $2.30 \%$ of the total of the products of debitage (Figure 9).

According to the type of angle of the retouch, we observed that the "semi-abrupt" angle is the most represented, followed by the "low angle". The "abrupt angle" represents $18.05 \%$ of the total of the retouched pieces and $3.74 \%$ of the total of the products of debitage. The "crossed abrupt" represents $5.55 \%$ of the retouched material and $1.16 \%$ of the total of the products of debitage. The semi-abrupt represents $40.27 \%$ of the retouched material and $8.35 \%$ of the total of products of debitage. The low angle does not represent a percentage, but the flush angle represents $37.5 \%$ of the retouched material and $7.78 \%$ of the total of the products of debitage (Figure 10).

According to the distribution of the retouch, the continuous represents $26.38 \%$ of the retouched material and $5.47 \%$ of the material product of the debitage. The discontinuous represents $2.77 \%$ of the retouched material and $0.57 \%$ of the material product of the debitage. Finally, the partial represents $70.83 \%$ of the retouched material and $14.69 \%$ of the material product of the debitage (Figure 11).

According to the extension of the retouch, we found that the short represents $83.33 \%$ of the retouched material and $17.29 \%$ of the material product of the debitage. The large one 
represents $16.66 \%$ of the retouched material and $3.45 \%$ of the total of the products of debitage (Figure 12).

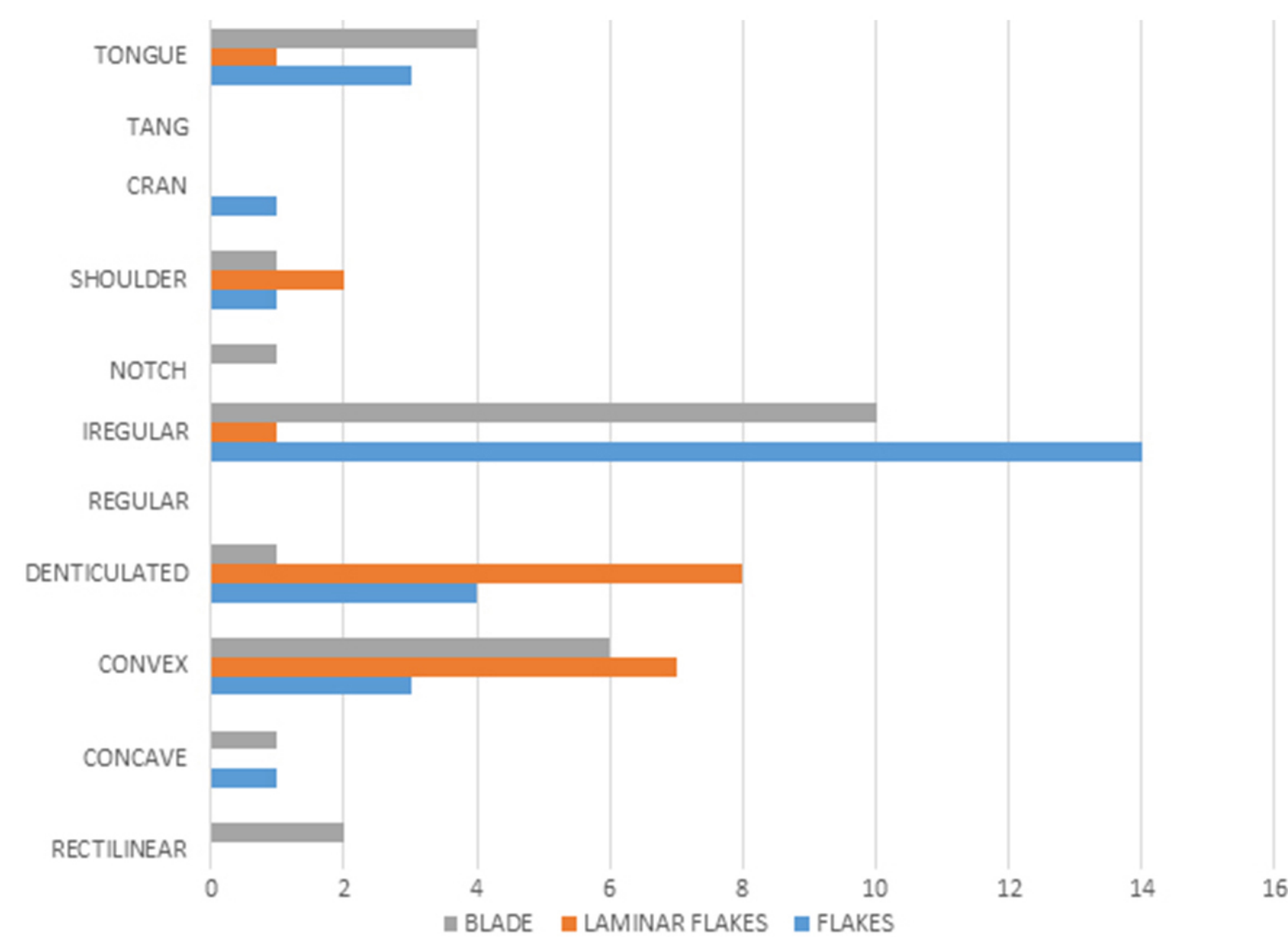

Figure 9. Representation of the type of delineation of the retouch.

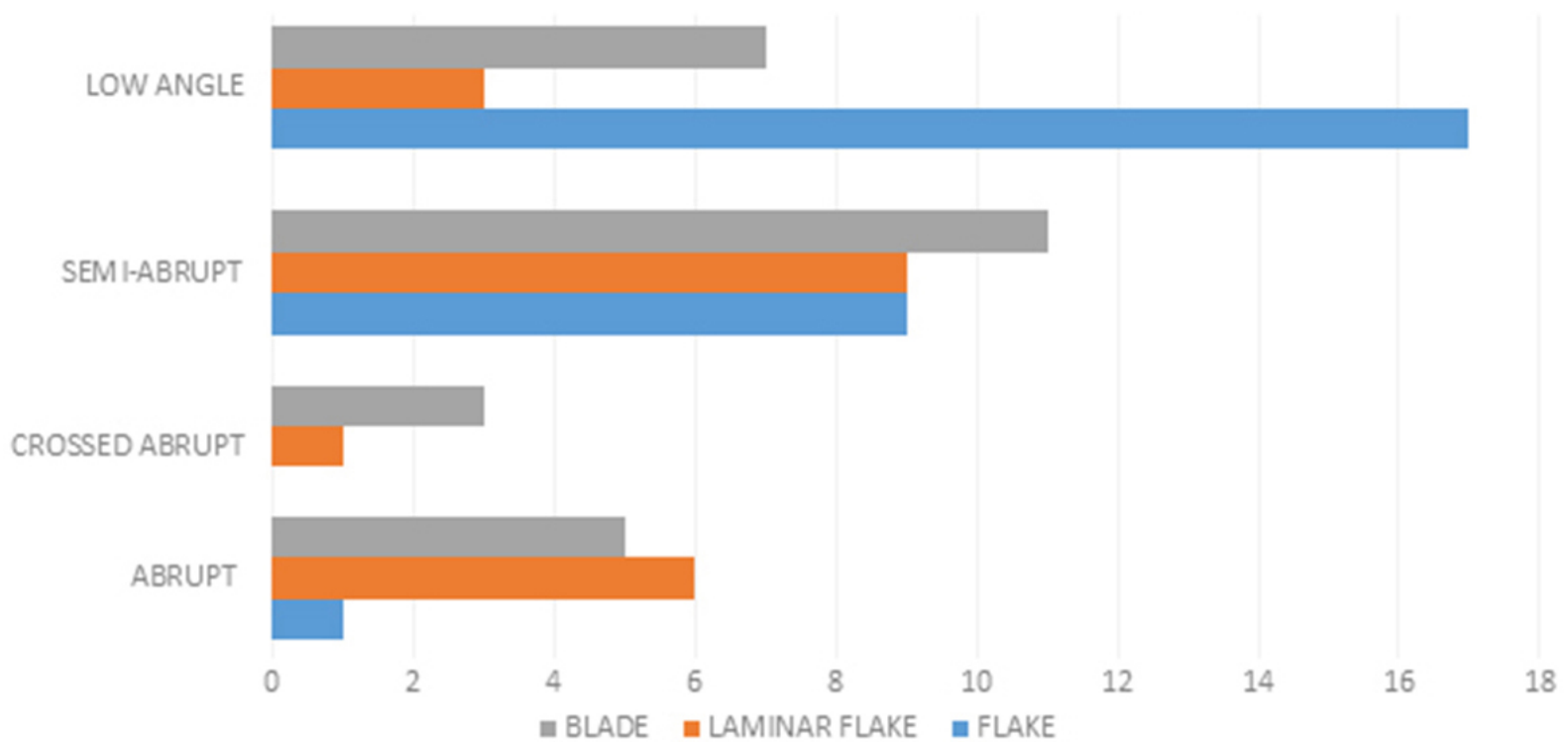

Figure 10. Representation of the angle of retouch from the total of retouched pieces. 


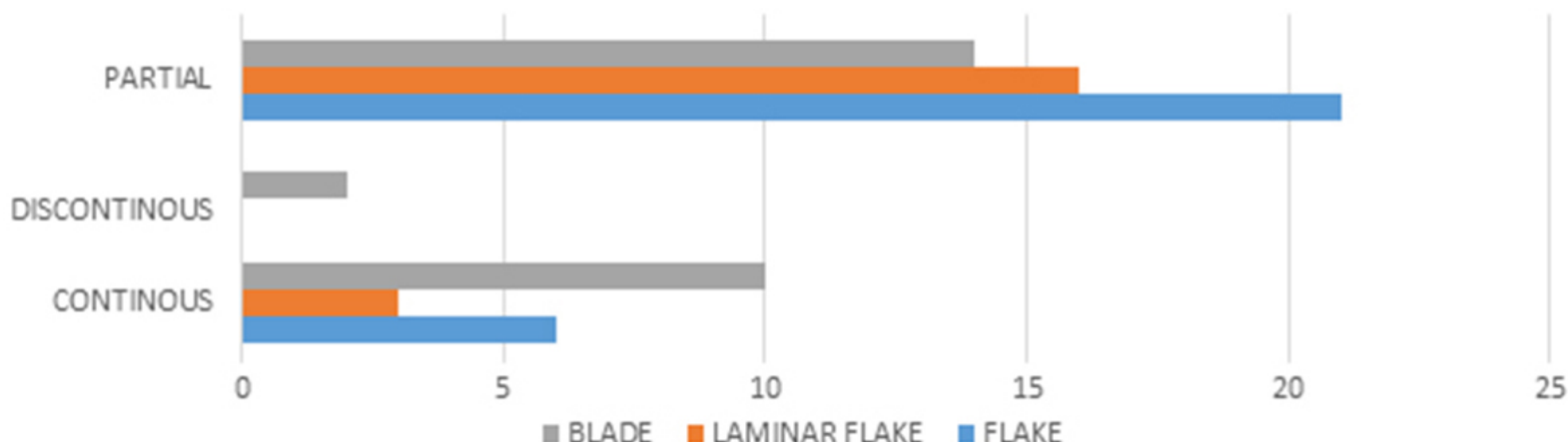

Figure 11. Representation of the distribution of the retouch from the retouched material.

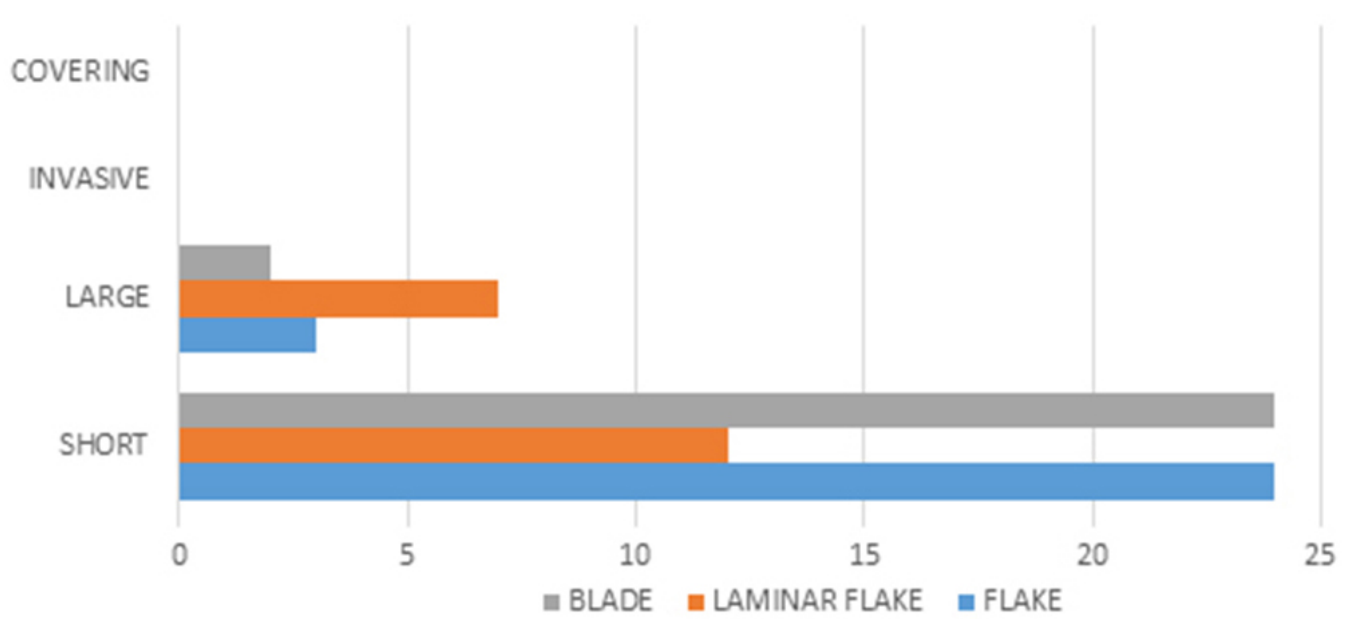

Figure 12. Representation of the extension of the retouch from the retouched material.

According to the morphology of the retouch, the scaled represents $1.38 \%$ of the retouched material and $0.28 \%$ of the material product of the debitage. The parallel retouch represents $37.5 \%$ of the retouched material and $7.78 \%$ of the material product of the debitage. The sub-parallel (sub-paralelo) represents $18.05 \%$ of the retouched material and $3.47 \%$ of the material product of the debitage; finally, the sub-parallel represents $43.05 \%$ of the retouched material and $8.93 \%$ of the material product of the debitage (Figure 13).

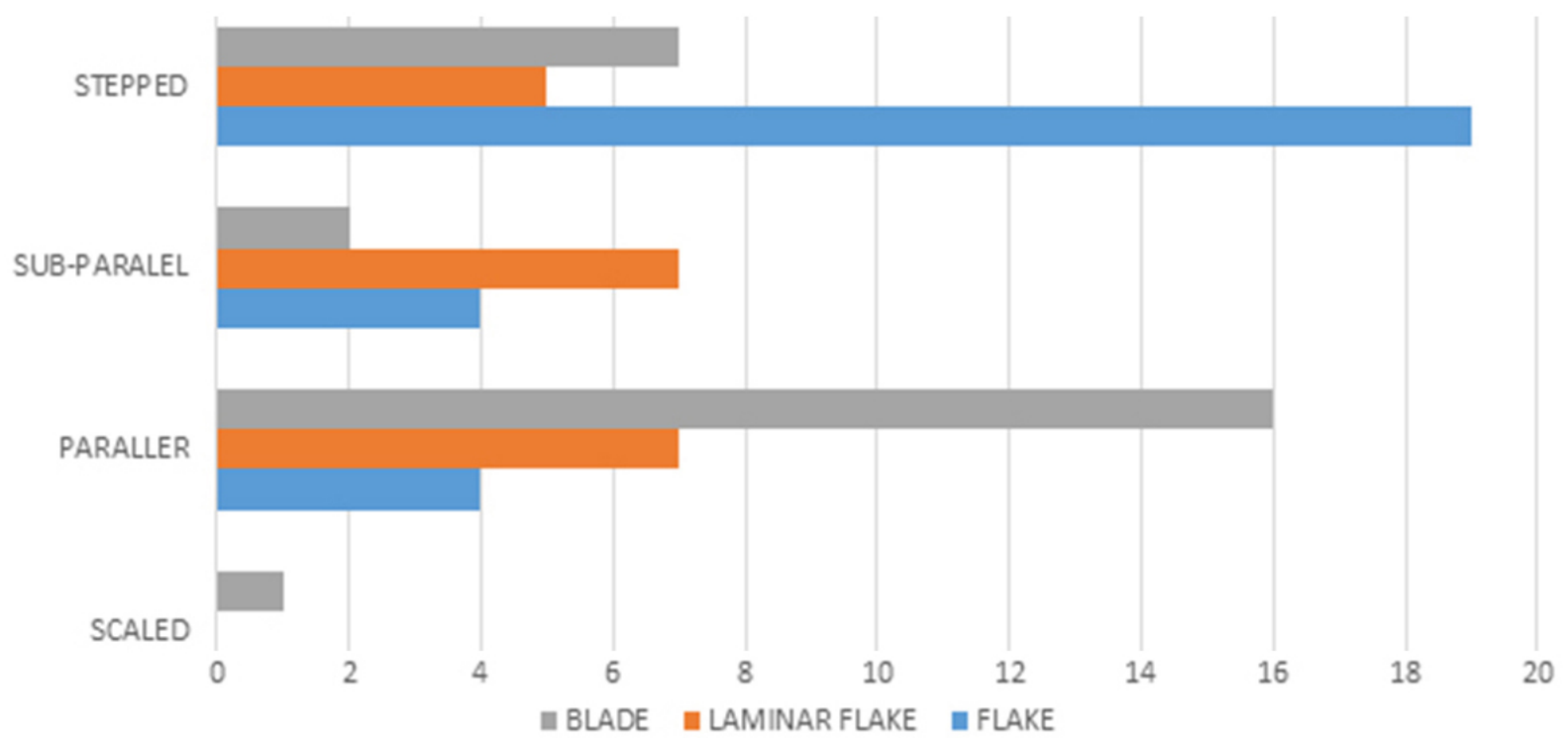

Figure 13. Representation of the morphology of the retouch from the retouched material. 


\section{Scrapers}

The scrapers are represented by 10 pieces. Its index corresponds to the $10.98 \%$ of the total of retouched pieces. We observe within the collection a large majority of frontal scrapers, which are normally manufactured over bladelets (Figure 14.4), and which also present a prepared front by simple and continuous retouch, generally rounded, sometimes rectilinear and rarely oblique. Its length is higher than the double of its width. The scrapers 1 , 2 and 7 (Figure 14) present simple retouches, abrupt or plain, in the laterals that gently continue the retouch of the front. The scrapers 5, 6 and 8 are plain scrapers over a laminar flakes prepared by a simple continuous retouch forming a rounded front, among other types of scrapers.

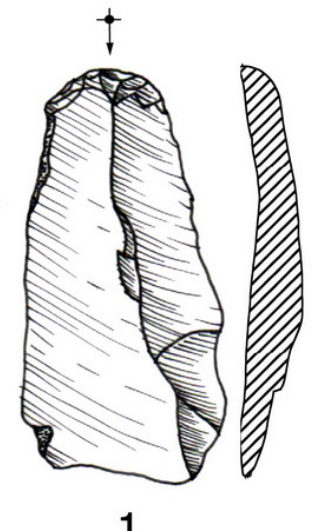

1

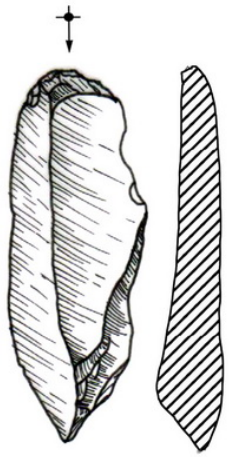

2

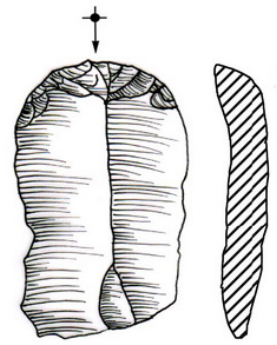

3

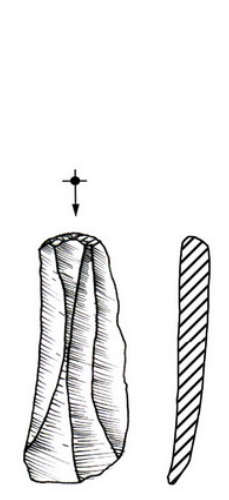

4

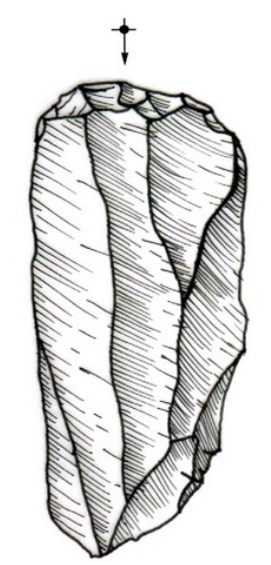

5
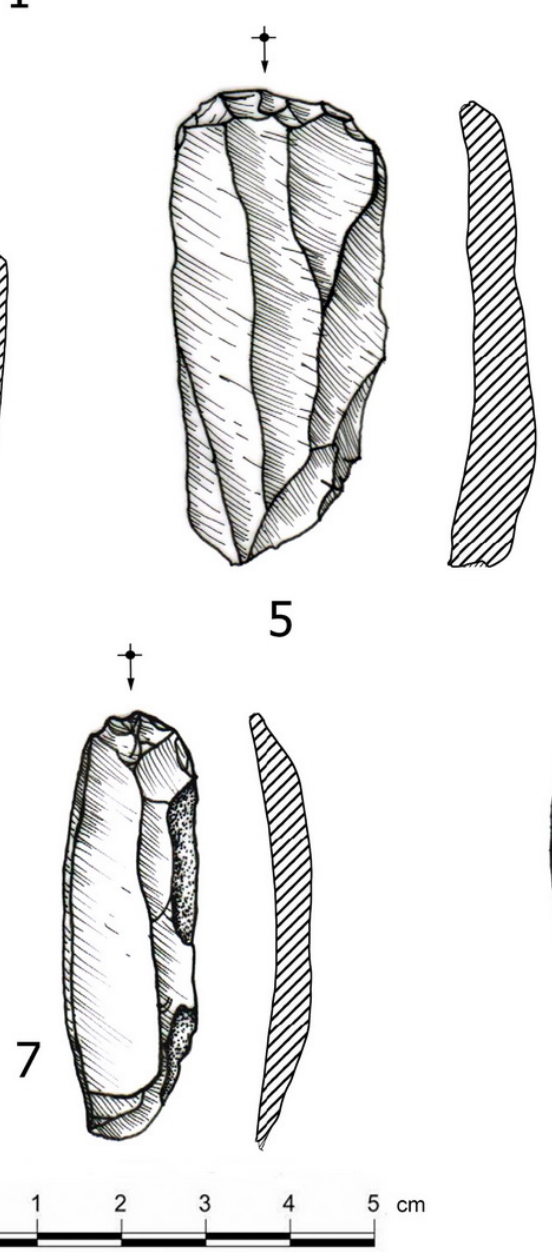

6
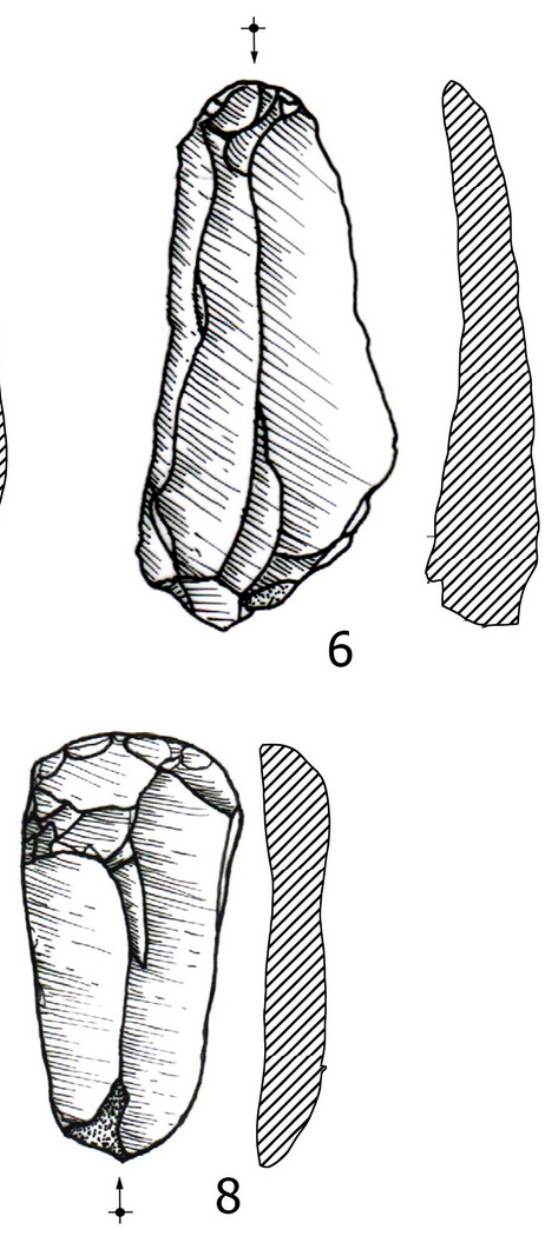

Figure 14. Collection of scrapers located at Tajo de Marchales. 


\section{Burins}

Taking the 19 pieces with the presence of burins spall (Figure 15), we found that the general index is $20.87 \%$. The index of dihedral burins is $4.39 \%$ and the index of dihedral burin restricted is $21.05 \%$. The index of burins over truncations is $5.49 \%$ and the index of the burins over truncations restricted is $26.31 \%$.

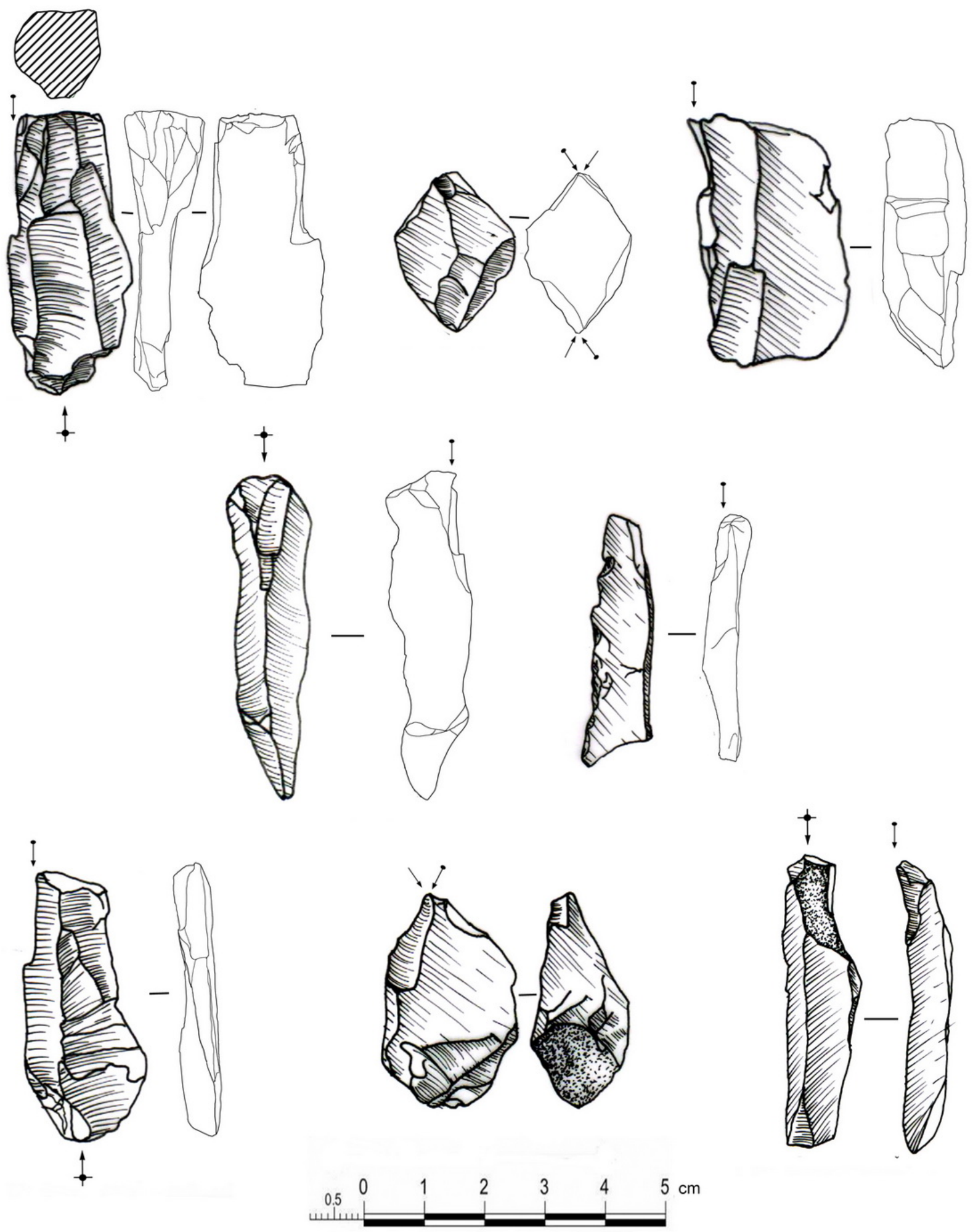

Figure 15. Collection of burins located at Tajo de Marchales. 
The burins spall follows the same principle of the debitage: making use of a natural or artificial platform of a support, and with the technique known as "burin spall", is removed through pressure or percussion along the edge of the prepared line. The burins spalls can be performed through the percussion with a hammer, and as a result, we can obtain burins facets (Inizan et al. 1999: 84).

The description of the retouch or burin spall was performed under two indicators: 1) burins facets and 2) The inclination of the burins facets. The simple burins represent $63.15 \%$ of the total of burins and $13.18 \%$ of the total of the retouched materials. The multiple burins represent $36 \%$ of the total of burins and $7.69 \%$ of the total of retouched pieces.

From the inclination of the burins facets, we can state the following:

1. The perpendicular inclination represents $36.84 \%$ of the total of burins and $7.69 \%$ of the total of the retouched material.

a. The perpendicular inclination from simple burins represents $21 \%$ of the total of burins and $4.39 \%$ of the total of the retouched material.

b. The perpendicular inclination from multiple burins represents $15.78 \%$ of the total of burins and $3.29 \%$ of the total of the retouched material.

2. The slightly angled inclination represents $42.10 \%$ of the total of burins and $8.79 \%$ of the total of retouched material.

a. The slightly angled inclination among simple burins represents $36.84 \%$ of the total of burins and $7.69 \%$ of the total of retouched material.

The slightly angled inclination of multiple burins represents $5.26 \%$ of the total of burins and $1.09 \%$ of the total of retouched material.

3. The inclination of the acute angle represents $21.05 \%$ of the total of burins and $4.39 \%$ from the total of retouched material.

a. The inclination of the acute angle represents $10.52 \%$ of the total of burins, for both simple or multiple burins, and $2.19 \%$ of the total of retouched material, for both simple and multiple burins.

\section{Drillers}

The materials identified as drillers represent $4.39 \%$ of the total of retouched materials; the 4 pieces belong to atypical over flakes and laminar flakes.

\section{Shoulders and denticulate}

The shoulders and denticulate have an index of $18.68 \%$, and we can observe an example in the Figure 16.2. Its higher representation was founded among denser pieces belonging to preliminary flaking supports.

\section{Backed and truncations tools}

The backed tools are represented by 12 items which represent $3.45 \%$ of the total of the products of debitage and $13.18 \%$ of the total of retouched items. We have blades with one or two retouched and abrupt edges (Figure 16.4).Within this material, we have two points that can be observed in the Figure 16.1. These two extended points are over narrow blades with rectilinear and slightly curved backs, dejected by abrupt retouches. Only in one case, we observed a sole retouched edge, in the second we can observe retouch in both edges, marginal and abrupt.

The typological analysis shows the burins as a typological group quantitatively superior $(20,87 \%)$ followed by the scrapers fundamentally over blades $(10,98 \%)$. Other groups as the 
shoulders (4,39\%) and denticulates (14,28\%) appear in less proportions. Finally, the group of abrupt retouched points, blades and backed bladelets (13.18\%) completes the series.
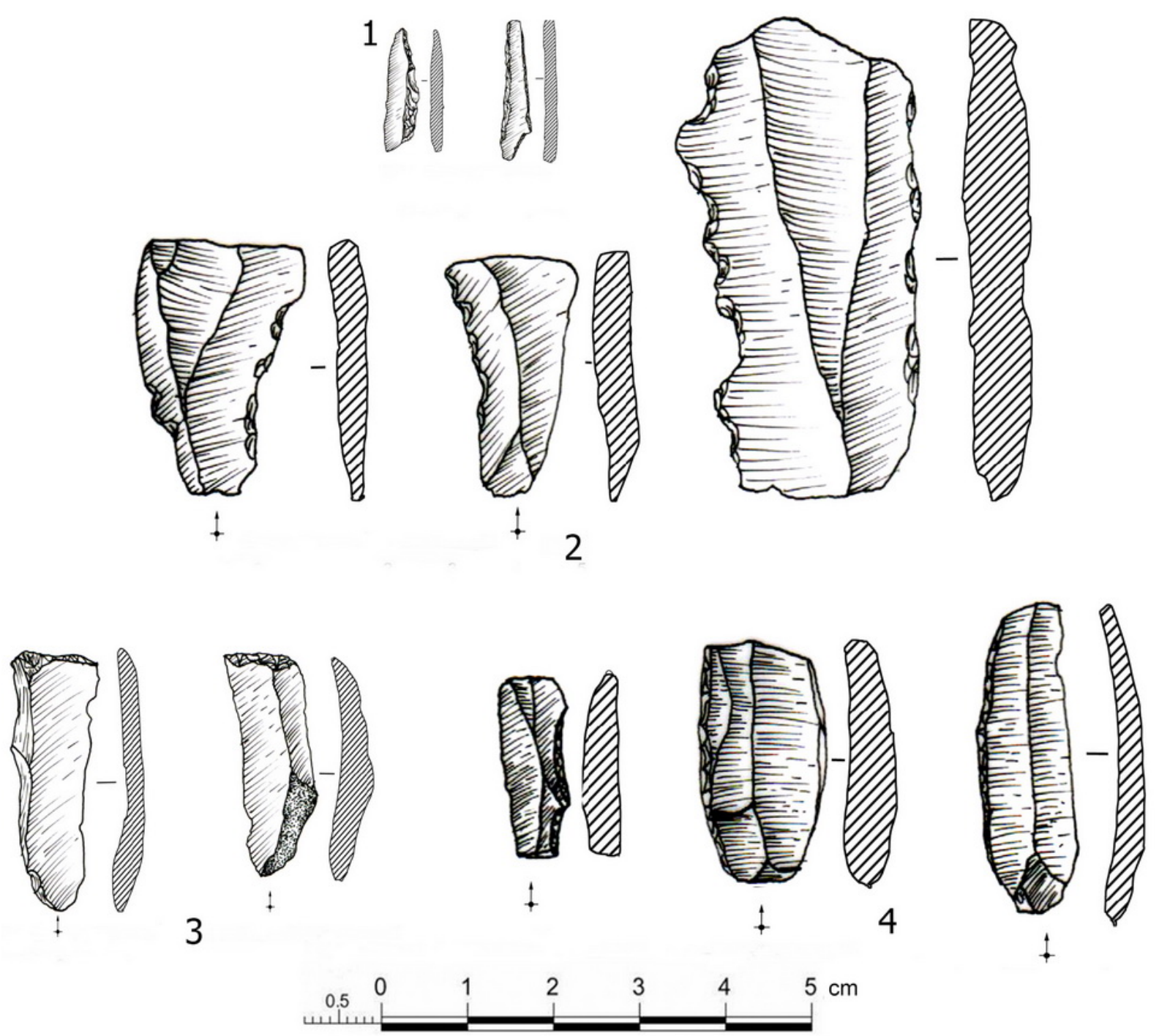

Figure 16. Collection of backed points, denticulates, truncations and backed blades located at Tajo de Marchales.

\subsection{Analysis of the method of debitage}

\section{Cores}

By definition, we consider the cores as natural blanks of raw material from which it can be extracted items like flakes or blades with the finality of obtaining blanks for the materials (Inizan et al. 1999: 20). Within the groups of cores with laminar tendency, we define several categories in relation to the type of product, its morphology and the orientation of the debitage: Frontal progression cores, unipolar cores with plain fontal progressions, unipolar core with sideward preparation (Figure 17), and bipolar cores (Figure 18). The total of laminar cores used for the study ascends to 12 items, and we performed the analysis of method of debitage to all of them.

a. Frontal progression cores: These are unipolar cortex-less cores in which we see a prominent and semi-rounded front of production. It can be observed in some examples the amortization due to accidents from the last extractions, represented by hinged negatives, which make them be abandoned. However they did not waste its potential as raw material. 


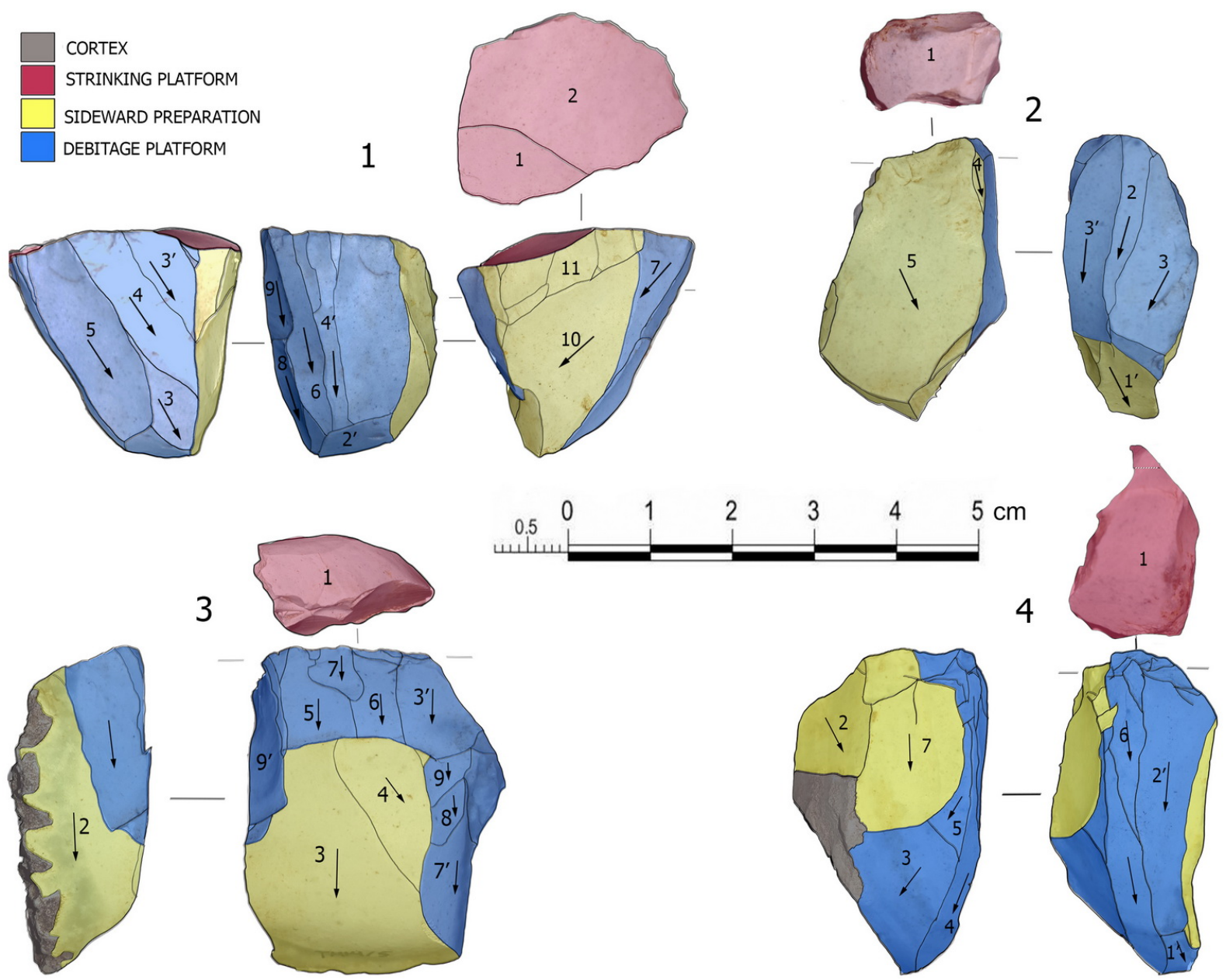

Figure 17. Assemblage of cores from Tajo de Marchales. 1, 2 and 4) Unipolar cores with plain frontal progression, 3) Frontal progression core.
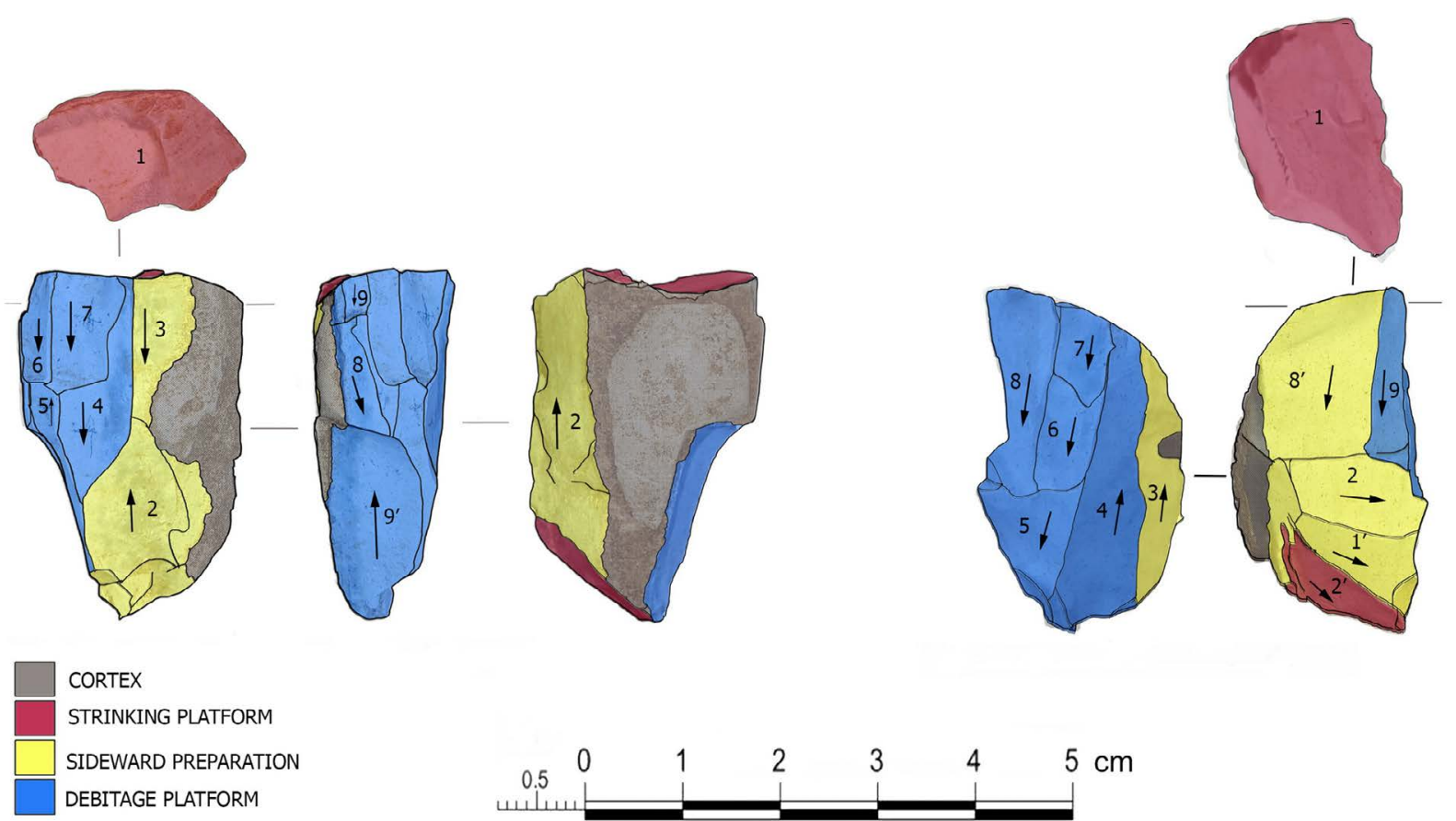

Figure 18. Assemblage of bipolar cores from Tajo de Marchales. 
The case of the core presented in the Figure 17.3 corresponds to a hinged flake which was used afterwards as a core. Its negative removals show that it was abandoned after an error of debitage, which provoked a hinged blade. We believe that the product of this debitage is manly referred to small size blades.

b. Unipolar cores with plain fontal progressions: The extractions are carried out on the only plain front. Only a few accidents of hinged flakes can be observed, with unidirectional and unipolar debitage of which its negatives show the extraction of blades and bladelets on such fronts of production. The laminar production within the assemblage predominates in this type of cores with semi-enveloping debitage (Figure 17.1-2-4).

c. Unipolar core with sideward preparation: In all the schemes of debitage (except in cores with bipolar debitage) it was observed some kind of lateral preparation. Although the difference that allows the isolation of this group comes from the presence of lateral ridges, which in this case appears reserved, or without extraction. This group presents a higher level of cortex.

d. Bipolar cores: A degree of preparation is observed on the percussion platform, which makes it seem that the debitage is not organized. The preparation of the percussion platform is made through the lateral thinning, obtaining a second percussion platform during the debitage, in such a way that the final product is a core of bipolar debitage. As with the unipolar cores, the discarded pieces are usually by the removal of flakes or hinged blades (Figure 18).

The accidents of debitage are present in the collection; the plunging flakes offered intriguing information about the methods of debitage of the cores. The most common scheme for the extraction of blades was the 2, 1, 2', being present in the only two cases that we registered. Likewise, the most technical aspects of the chaîne opératoire were present; such is the case of the crest blades used for the preparation of fronts of debitage, of which analysis show us the management of the material for the exploitation and extraction of blades. The majority of the cases showed a transversal debitage, usual in the preparation of cores and, in some cases (third crest blades from left to right), presented a unidirectional debitage in the dorsal face and bipolarity in the ventral face.

\section{Laminar flakes and blades}

We selected the laminar elements among the totality of the material product of the debitage, and the count showed the existence of 166 items. The analysis of the material product of the debitage showed us an increase regarding the bipolar debitage that was present in the levels close to the material of internal debitage. The unipolar debitage is maintained along the sequences of debitage with some laminar flakes of tranversal debitage that, although with low presence, were observed at the preparation levels (Figure 19).

Group 1: Laminar flakes, all of which present a unipolar debitage. The items from the first group, flakes and laminar flakes alike, have a representation of $4.68 \%$ from the total of materials without retouch.

Group 2: 12 laminar flakes, all of them show a unipolar debitage. The items from this group, flakes and laminar flakes alike, have a representation of $9.37 \%$ of the total of material without retouch.

Group 3: 23 of laminar flakes which represent $16.79 \%$ of the total of material without retouch.

Group 4: 50 items comprise it; the laminar flakes from this group have a representation of $19.53 \%$ of the total of material without the presence of retouch and all of them present unipolar debitage. 
Group 5: With 74 items, the fifth group has a representation of $28.90 \%$ of the total of the items without retouch. We find, in this last stage of transformation, bipolar debitage blades, i.e. the axis of debitage and the morphological axis are opposed to each other. Among the $26.90 \%$ of blades belonging to this group, $5.36 \%$ are bipolar, representing $48 \%$ of the total of items of the fifth group.

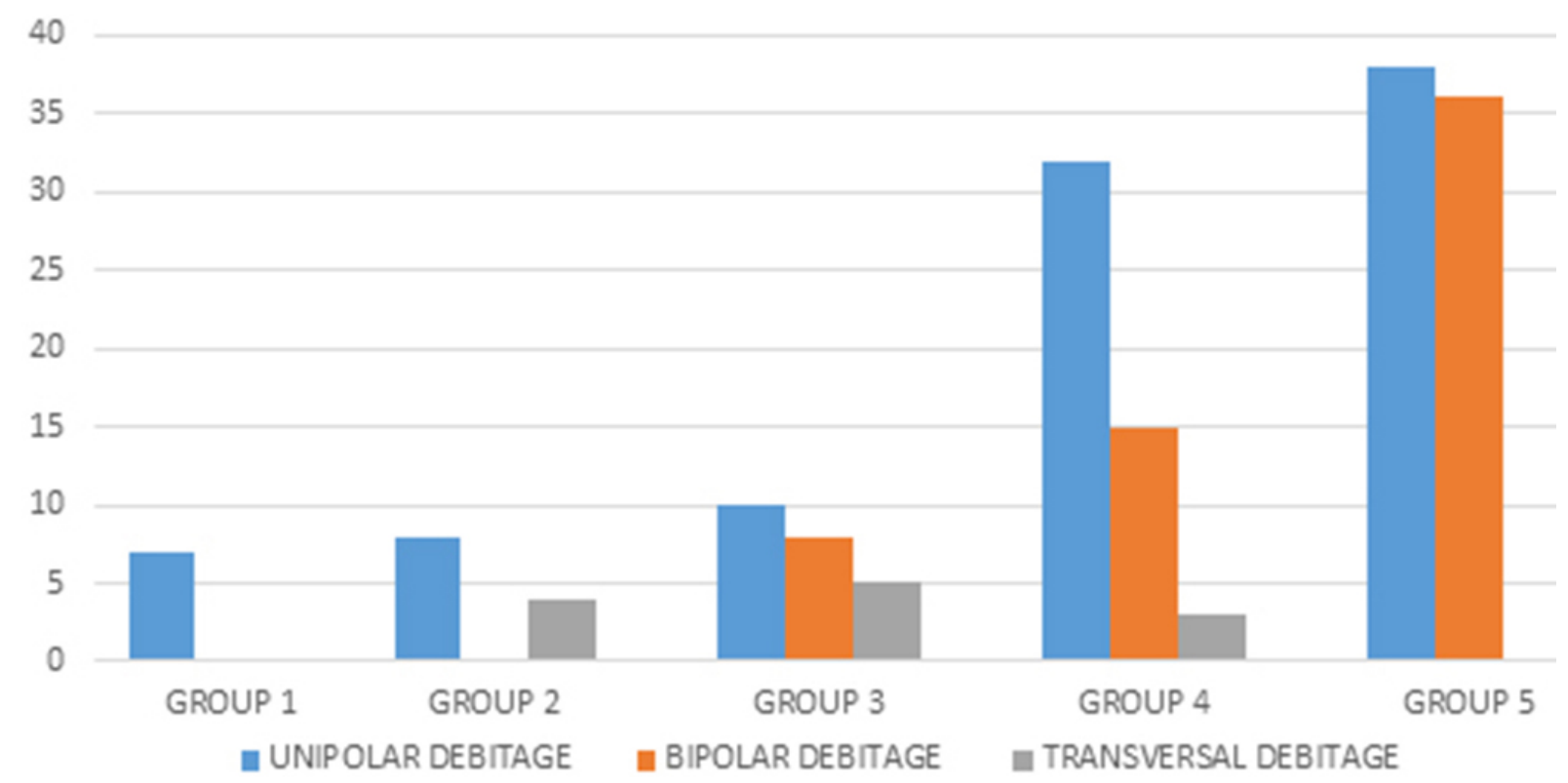

Figure 19. Technological analysis of laminar flakes and blades.

\subsection{Transformation process}

The management of raw material and its proper location within the early stages of the chaîne opératoire is not an easy task; even more if the sample is skewed from specific chrono-stratigraphic information that may enable the establishment of straight temporal parameters (Figure 20).

The initial character of the lithic products is evident, the corticality of the blanks, the size, the technique, and the method of debitage are proofs of it and additionally demonstrate the presence of the first stage of debitage, as well as the later phases. During the analysis of the lithic assemblage from Marchales, we identified the different phases of the chaîne opératoire, from the early stages until the abandonment of the cores.

The assemblage has presence of supports from different stages, since the shortage of raw material is an indicator of this. Therefore, we identified the groups that were explained in the last chapter. The cortex removal implies the cortical cleaning of the natural blank that will be submitted to debitage (Groups 1 and 2), i.e. materials with more than 50\% of cortical surface (Group 1) and materials with a cortical surface lower than 50\% (Group 2). In the second group we found 8 retouched blanks (8.79\%). The preliminary flaking material can be of two types: 1) material with cortical surface lower than $50 \%$ and presence of negatives removals in the dorsal face, 2) material without the presence of cortical surface and presence of negatives removals in the dorsal face (Groups 3 and 4). We found 42 retouched supports with this characteristic (46.15\%). The $5^{\text {th }}$ group is made of 41 retouched supports (45.05\%).

The diacritic reading performed to these cores and products of debitage shows unipolar and bipolar method of debitage, with cores of frontal progression or semi-enveloped, and also some core-like burins from which the most narrowed bladelets were obtained. 


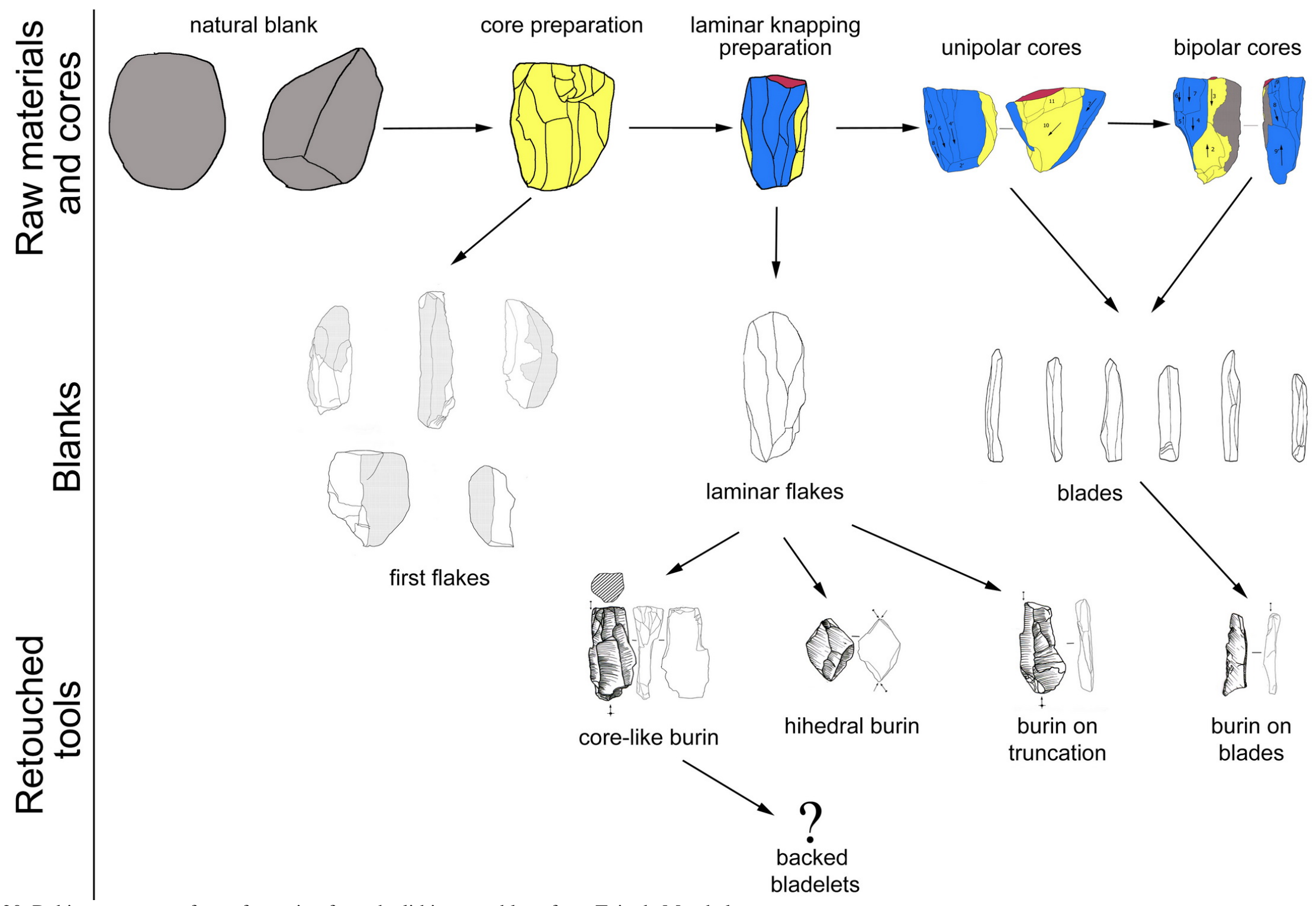

Figure 20. Debitage process of transformation from the lithic assemblage from Tajo de Marchales. 
In the technological analysis performed to the pieces without the presence of retouch, we observed that the flakes from the fourth group presented a bipolarity of $3.90 \%$, and, in the laminar flakes case we did not observe bipolarity, and finally, the blades from the fifth group presented a bipolarity of $14.06 \%$. In some regard, the low percentage of bipolarity in the flakes within the fourth group is understandable because they are regularization flakes of cores. The last goal of the chaîne opératoire does not end with the production of flakes, but these are extracted and employed for the preparation of a core and the seeking of laminar debitage platforms. The fifth group is composed of blades which present a relative high level of bipolarity. The diacritic analysis employed to the cores made us conclude that the bipolarity is an intentional decision of debitage, which may or may not be carried out. This action will be carried out if needed but it will not be its main finality.

The analysis of the lithic assemblage from Marchales allowed the identification of the different phases of the chaîne opératoire for the elaboration of tools over blades and bladelets. The analysis of cores, supports and retouched objects enable the aggrupation of the material into three groups:

1. The widest and thickest supports from the earliest stages of the preparation of laminar cores are fundamentally intended for the elaboration of scrapers and denticulates. The scrapers over laminar flakes of preliminary flaking represent $8.79 \%$ of the total of retouched material, with only one scraper over blade. In regard of the denticulates and shoulders, we have two pieces corresponding to cortex removal items (2.19\%). 10 correspond to preliminary flaking (10.98\%), and 5 to internal debitage $(5.49 \%)$. All of this shows a strong tendency to the searching of big sized laminar supports.

2. The exhaustive laminar debitage of cores aims to obtain laminar supports (blades and bladelets) which, through abrupt retouch, offer backed tools and points. The index of the total of retouched backed pieces is $13.18 \%$.

3. The obtaining of burins spalls is performed in supports which belong to flakes $(6.59 \%)$, laminar flakes (10.98\%), and blades (3.29\%). We have three principal types of burins: core-like burins, dihedral and burins over truncations. As a result of the high presence of blades and bladelets we maintain the hypothesis that some of the types of burins are used for the elaboration of backed tools.

Even though we divided the material into three chaines for providing a simpler explanation, we must keep into account that this material comes from the surface and, although it keeps some homogeneity, these conclusions must be treated with caution since only more intensive studies as well as the search for chrono-stratigraphy, could offer more information.

\section{Discussion}

Having obtained both indexes from the cited deposits and Tajo de Marchales, we can conclude that there is a great resemblance to the indexes of Pantano de Cubillas in regard to the index of scrapers, although in the case of the burins, the former do not present such an elevated index as the latter (Table 1). Likewise, there is some kind of relation to Pirulejo 4 with regard to the 3 layers corresponding to this denomination. In all three of them there is a correlation of indexes of scrapers and burins. The indexes which present confusion are the shoulders and denticulates which show a highly elevated index in comparison to what we are normally observing in the deposits.

We need to be cautious with the formal ascription of the lithic collection from Tajo de Marchales because it comes from a superficial recovery. However, the formal characteristics, its technology, and its comparison with the cited deposits enable us to formulate the following conclusion for its chrono-cultural definition. 
Table 1. Comparison with other material indexes of the zone. Abbreviations: IG - scraper index ("indice de rapadores" in Spanish); IB - burin index (Spanish: "indice de buriles"); IBd - dihedral burin index (Spanish:

"indice de buriles dihedros"); IBt - burin index over truncation (Spanish: "indice de brusil sobre truncatura"); Ibc

- drill-perforator index (Spanish: "indice de perforadores"); Imd - shoulder and denticulate index (Spanish:

"indice de muescas y denticulados"); IT - truncation index (Spanish: "indice de truncadura").

\begin{tabular}{lcccccccl}
\hline & IG & IB & IBd & IBt & Ibc & Imd- & IT & \\
\hline El Duende & 10.5 & 6.2 & & & 0.7 & 2.8 & & Epi-paleolithic \\
Pantano de Cubillas & 10.6 & 14.6 & 8.6 & 3.3 & 0.6 & 17.3 & 22.7 & Solutrean-Gravettian \\
Bajontillo 11 & 29.1 & 16.4 & 7.3 & 22.2 & 7.3 & 18.2 & 1.8 & Aurignacian \\
Bajondillo 10 & 17.2 & 31 & 10.3 & 10.3 & 6.9 & 13.8 & 6.9 & Gravettian \\
Bajondillo 6, 7, 8 & 22.7 & 25 & 12.21 & 12.1 & 3 & 4.5 & & Solutrean-Gravetiian \\
Pirulejo 4d & 11 & 28.8 & 17.8 & 0 & 0 & 5.5 & 2.7 & Magdalenian \\
& 11.9 & 22.4 & 19.4 & 0 & 0 & 6 & 3 & Magdalenian \\
& 6.3 & 23.8 & 20.6 & 0 & 0 & 6.3 & 3.2 & Magdalenian \\
Pirulejo 4 & 13.2 & 22.2 & 17.4 & 1.8 & 3 & 4.2 & 1.2 & Magdalenian \\
Pirulejo 3 & 12.1 & 18.6 & 11.4 & 4.3 & 2.1 & 3.6 & 2.1 & Upper Magdalenian \\
Pirulejo 2 & 19.6 & 13 & 10.9 & 2.2 & 2.2 & 4.3 & 0 & Epi-paleolithic \\
El Tajo de Marchales & 10.9 & 20.8 & 4.3 & 5.4 & 4.39 & 18.6 & 2.1 & \\
\hline
\end{tabular}

The lithic assemblage from Abrigo 3 may correspond, sensu lato, to the Early Magdalenian. Specifically, the characteristic types of burins, its proportion with the assemblage of typological groups, and the incidence of backed tools, along with the presence of backed points, with an absence of geometrical elements, point to distinctive traits from the early stages of the Mediterranean Magdalenian, immediately after the Badegulian defined in Parpalló and other deposits from this region (Aura 2004; Aura et al. 2012). On the other hand, the typometry and the low incidence of backed microbladelets keep it away from the tendencies of the Upper Magdalenian, strengthening the attribution of the characteristics of the initial laminar technology into the Initial Magdalenian techno-complex of the region.

Some authors (Bosselin \& Djindjian 1998; Bosselin 2000; Langlais et al. 2010) highlight the existence of industries of flaking predominantly laminar, and the manufacturing of tools over bladelets at 15000. B.P., named as facies M2 (Cortés 2008).

The so far known assemblage of Abrigo 3 de Marchales corresponds to one of the first superficial recoveries as a consequence of the destruction of the most recent levels of the shelter, and also of the changes that happened at the final stages of the $20^{\text {th }}$ century when the Mediterranean understory was substituted by an Olive field. Due to all of these reasons, we are cautious for the establishment of a concrete sequential definition, which should be corroborated in further interventions. Nevertheless, the known archaeological assemblage has allowed us to reaffirm its formal characteristic which, along with the comparison with other deposits, places it into the assemblages from the Upper Paleolithic and, sensu lato, to the Archaic Mediterranean-Magdalenian. This cultural ascription is made having in mind the characteristic types of burins, their proportion with the rest of the typological groups, and the incidence of backed tools, along with the presence of backed points, with a lack of geometrical elements, immediately after the Badegoulian defined at Parpalló and other deposits from this region (Aura 1995; Aura et al. 2012). Otherwise, the typometry and the low incidence of backed microbladelets place it away from the tendency of the Upper Magdalenian. 


\section{References}

Aura, J. \& Perez, C. 1998, ¿Micropuntas dobles o anzuelos? Una propuesta de estudio a partir de los materiales de la Cueva de Nerja. In: Las culturas del Pleistoceno Superior en Andalucia (Sanchidrián, J.L. \& Simón, M.D., Eds.), Patronato de la Cueva de Nerja, Málaga: p. 339-348. (in Spanish) ("Double Micropunts or hooks? A proposal of study from the materials of the Cueva de Nerja”)

Aura, J. \& Perez, M. 1992. Tardiglaciar y postglaciar en la región mediterrânea de la Península Ibérica (13,500-8,500 BP.): Transformaciones industriales y económicas. PLAV-Sagvmtvm, 25: 25-48. (in Spanish) ("Tardiglaciar and postglaciar in the Mediterranean region of the Iberian Peninsula (13,500-8,500 BP.): Industrial and economic transformations”) doi:10.7203/SAGVNTVM..3646

Aura, J. \& Villaverde, V. 1995, Paleolítico Superior final y Epipaleolítico antiguo en la España mediterránea (18.000-9.000 B.P). In: El final del Paleolítico Cantábrico (Moure, A. \& González, C., Eds.), University of Cantábria, Santander: p. 313-340. (in Spanish) (Final Upper Paleolithic \& Ancient Epipaleolithic in the mediterranean Spain)

Aura, J. 1986. La ocupación magdaleniense de la cueva de Nerja (la sala de la Mina). La Prehistoria de la Cueva de Nerja (Málaga). In: Trabajos sobre la Cueva de Nerja, $n^{\circ} 1$. Paleolítico y Epipaleolítico (J.F., Ed.), Patronato de la Cueva de Nerja, Málaga: p. 205268. (in Spanish) ("The Magdalenian occupation of the cave of Nerja (the room of the Mine). The Prehistory of the Cave of Nerja (Málaga”)

Aura, J. 1988. La Cova del Parpalló y el Magdaleniense de Facies Ibérica. Propuesta de sistematización de su cultura material: Industria lítica y ósea. Ph.D. thesis, University of Valencia, Valencia, 560 p. (in Spanish) ("La Cova del Parpalló and the Magdalenian of Facies Ibérica. Proposal of systematization of its material culture: Lithic and bone industry")

Aura, J. 1989. Solutrenses y Magdalenienses al sur del Ebro. Primera aproximación a un proceso de cambio tecnoindustrial: El ejemplo de Parpalló. PLAV-Sagvmtvm, 22: 35-65. (in Spanish) ("Solutrean and Magdalenians to the south of the Ebro. First approach to a process of technoindustrial change: The example of Parpalló”)

URL: http://roderic.uv.es/handle/10550/34949

Aura, J. 1995. El Magdaleniense Mediterráneo: La Cova del Parpalló (Gandía, Valencia). Serie de trabajos varios Vol. 91. Diputación Provincial, Valencia, 216 p. (in Spanish) (“The Mediterranean Magdalenian: La Cova del Parpalló, Gandía, Valencia”) URL: http://www.museuprehistoriavalencia.es/web_mupreva/publicaciones/?q=fr\&id=1 22

Aura, J. 1997. Al sur del Ebro. Badeguliense y Magdaleniense en la región mediterránea (ca. 17.000-11.000 BP). In: El món mediterrani després del Pleniglacial (18.000-12.000 B.P.) (Pericot, J. \& Masferrer, N., Eds.), Serie monográfica Vol. 17, Centre d'Investigacions Arqueològiques, Girona: p. 243-254. (in Spanish) ("South of the Ebro, Badegulian and Magdalenian in the Mediterranean region, ca. 17,000-11,000 BP”)

Aura, J. 2007. Badegouliens et Magdaléniens du versant méditerranéen espagnol. Bulletin de la Societé Prèhistorique Française, 104(4): 809-824. (in French) ("Badegoulians and Magdalenians of the Spanish Mediterranean slope”) doi:10.3406/bspf.2007.13625

Aura, J., Jordá, J., Avezuela, B., Perez, M., Tiffagom, M., \& Morales, J. 2010. La Cueva de Nerja (Málaga, España) y el Gravetiense en Andalucía. In: Cuaternario y Arqueología: 
Homenaje a Francisco Giles Pacheco (Mata, E., Ed.), Diputación Provincial de Cadíz, Cadíz: p.125-132. (in Spanish) ("The Cave of Nerja (Malaga, Spain) and the Gravetiense in Andalusia”)

Aura, J., Jordá, J., Gonzalez-Tablas, J., Becares, J. \& Sanchidrian, J. 1998. Secuencia arqueológica de la Cueva de Nerja; La sala del Vestíbulo. In: Las Culturas del Pleistoceno Superior em Andalucía (Sanchidrián, J.L. \& Simón, M.D., Eds.), Patronato de la Cueva de Nerja, Málaga: p. 217-236. (in Spanish) (“Archaeological sequence of the Cave of Nerja; The Lobby Room”)

Aura, J., Jordá, J., Perez, M., Badal, E., Morales, B. 2010b. Treinta años de investigación sobre el Paleolítico superior de Andalucía: La Cueva de Nerja (Málaga, España). In: Jornadas Internacionales sobre el Paleolítico superior peninsular. Novedades del siglo XXI (Mangado, X., Ed.), University of Barcelona, Barcelona: p. 150-172. (in Spanish) ("Thirty years of research on the Upper Paleolithic of Andalusia: The Cueva de Nerja, Malaga, Spain”)

Baena Preysler, J. \& Cuartero, F. 2006, Más allá de la tipología lítica: Lectura diacrítica y experimentación como claves para la reconstrucción del proceso tecnológico. Zona Arqueológica, 7(1): 145-160. (in Spanish) ("Beyond the lithic typology: Diacritical reading and experimentation as key to the reconstruction of the technological process”)

Cahen, D., Keeley, L., Karlin, C. \& Van, F. 1980. Méthodes d'analyse technique, spatiale et fonctionnelle d'ensembles lithiques, Helinium, 20: 209-259. (in French) ("Methods of technical, spatial and functional analysis of lithic ensembles”)

Carbonell, E., Rodríguez, J., Sala, R., \& Vaquero, M. 1992. New Elements of the logical Analytic system. In: First International Meeting on Technological Systems to Configure Lithic Objects of Scarce Elaboration, Vol. 6 (Carbonell, E., Rodríguez, X.P., Sala, R. \& Vaquero, M., Eds.), Cahier Noir, Tarragona: p. 50- 61.

Castañeda, N. 2011. Diagrama dinâmico de secuencias de reducción: Aproximación metodológica para el análisis de los núcleos líticos y remontajes (DRS). In: $L a$ investigación experimental aplicada a la Arqueología (Morgado A., Baena, J., \& García, D., Eds.), Departamento de Prehistoria y Arqueología Universidad de Granada, Granada: p. 215-230. (in Spanish) ("Dynamic reduction sequence diagram: Methodological approach for the analysis of lithic nuclei and reassembly, DRS”)

Castañeda, N. 2015. Diagrama de secuencias de reducción (DRS): Aproximación metodológica para el análisis de núcleos líticos y remontajes. In: Seis Décadas de tipología analítica, actas en homenaje a Georges Laplace (Calvo, A., Sánchez, A., García-Rojas, M., \& Alonso, M., Eds.), Universidad del País Vasco, Vitoria-Gasteiz: p. 92-104. (in Spanish) ("Dynamic reduction sequence diagram (DRS): Methodological approach for the analysis of lithic nuclei and reassembly")

Cortés, M. (Ed.) 2007. Cueva Bajondillo (Torremolinos). Secuencia cronocultural y paleoambiental del Cuaternario reciente en la Bahía de Málaga. Servicio de Publicaciones y Divulgación Científica de la Universidad de Málaga, Málaga, 546 p. (in Spanish) (“Cave Bajondillo (Torremolinos). Chronocultural and paleoenvironmental sequence of the recent Quaternary in the Bay of Malaga”)

Cortés, M. (Ed.) 2008. Cazadores recolectores del paleolítico superior en la sierra Subbética. Estudios en Homenaje a la professora Maria Dolores Asquerino. ANTIQVITAS, 20: 213221 (in Spanish) (Upper Paleolithic collecting hunters in the Sierra Subbetica) doi:10.3989/tp.2012.12076 
Cortés, M. 2002. El Paleolítico Medio y Superior en el sector central de Andalucía (Cordoba, y Málaga). Doctoral Thesis. University of Málaga, Málaga, 194 p. (in Spanish) (The Middle and Upper Paleolithic in the central sector of Andalusia (Cordoba, and Malaga)

Cortés, M. 2010. El paleolítico Superior en el sur de la península Ibérica. Un punto de partida a comienzos del siglo XXI. In: El paleolítico superior peninsular. Novedades del siglo XXI, (Mangado, X., Ed.), University of Barcelona, Barcelona: p. 133-156. (in Spanish) ("The Upper Paleolithic in the south of the Iberian peninsula. A starting point at the beginning of the 21st century”)

Dauvois, M. 1976, Précis de dessin dynamique et structural des industries lithiques préhistoriques. Pierre Fanlac - Centre national de la recherche scientifique (CNRS), Périgueux, 263 p. (in French) ("Precis of dynamic and structural drawing of prehistoric lithic industries”) URL: http://trove.nla.gov.au/version/12969909

De la Peña, P. 2001. Sobre la Identificación macroscópica de las piezas astilladas: Propuesta experimental. Trabajos de Prehistoria, 68 (1): 79-98. (in Spanish) ("On the macroscopic identification of chipped parts: Experimental proposal”) doi:10.3989/tp.2011.11060

De la Peña, P. 2009. Revisión de los conjuntos gravetienses y su contexto arqueológico en la península Ibérica. COMPLVTVM, 20 (1): 29-53. (in Spanish) ("Review of the archaeological gravettian sites in their archaeological context in the Iberian Peninsula") URL: http://revistas.ucm.es/index.php/CMPL/article/view/CMPL0909120029A

De la Peña, P. 2012. Sobre la unidad tecnológica del Gravetiense en la Península Ibérica: implicaciones para el conocimiento del Paleolítico Superior inicial. Doctoral Thesis. University of Madrid, Madrid, 452 p. (in Spanish) (On the technological unit of the Gravetiense in the Iberian Peninsula: Implications for the knowledge of the initial Upper Palaeolithic)

Demasrs, P. \& Laurent, P. 1992. Types d'outils lithiques du paléolithique superieur en Europe. Presses du CNRS, Paris, 178 p. (in French) ("Types of topical paleolithic lithic tools in Europe")

Ferrer, J., Marqués, I., Baldomero, A., Ramos, J. 2005. Excavaciones en Cueva del Hoyo de la Mina (Málaga, Andalucía, España). Contrastación de una secuencia arqueológica clásica para el estudio del Tardiglaciar- Holoceno antiguo en el sur de la Península Ibérica. In: Reunión de la Cuenca mediterránea durante el Paleolítico superior (38.00010.000). IV Simposio de Prehistoria Cueva de Nerja y Reunión de la VIII Comisión de la U.I.S.P.P (Sanchidrián, J., Márquez, A. \& Fullola, J., Eds.), Fundación Cueva de Nerja, Málaga: p. 316-325. (in Spanish) ("Excavations in Cave of the Mine of the Mine (Malaga, Andalusia, Spain). Contrast of a classical archaeological sequence for the study of the ancient Tardiglaciar-Holocene in the south of the Iberian Peninsula”)

Fortea, J. 1985. El paleolítico y Epipaleolítico en la región central del Mediterráneo peninsular: Estado de la cuestión industrial. LVCETVM, 3: 20-30. (in Spanish) ("The Paleolithic and Epipaleolithic in the central region of the peninsular Mediterranean: State of the industrial question”) doi:10.14198/LVCENTVM1985.Anejo.03

Fortea, J. 1973. Los complejos microlaminares y geométricos del Epipaleolítico Mediterráneo Español. Memorias del Seminario de Prehistoria y Arqueología, Vol. 4. University of Salamanca, Salamanca, 550 p. (in Spanish) (The microlaminar and geometric complexes of the Spanish Mediterranean Epipaleolithic) 
Fortea, J. 1986. El Paleolítico Superior y Epipaleolítico en Andalucía. Estado de la cuestión cincuenta años después. In: Actas del Congreso Homenaje a Luis Siret, (Junta de Andalucía), Conseria de Cultura, Sevilla p. 67-78. (in Spanish) (“The Upper Palaeolithic and Epipaleolithic in Andalusia. State of the question fifty years later”)

Fullola, J. 1979. Las industrias líticas del Paleolítico Superior Ibérico. Series de trabajos vários Vol. 60. Diputación Provincial de Valencia, Valencia, 253 p. (in Spanish) (“The lytic industries of the Upper Iberian Paleolithic")

URL: http://www.museuprehistoriavalencia.es/web_mupreva_dedalo/publicaciones/91/ es

Fullola, J., Villaverde, V., Sanchidrían, J., Aura, J., Fortea, J., Soler, N. 2005.El Paleolítico superior Mediterráneo Ibérico. In: La Cuenca Mediterránea durante el Paleolítico superior 38.000-10.000 años. IV Simposio de Prehistoria Cueva de Nerja (Sanchidrián, J., Márquez, A. \& Fullola, J., Eds) Fundación Cueva de Nerja, Málaga: p. 192-213. (in Spanish) ("The Upper Iberian Mediterranean Paleolithic")

Garanger, J. 2002. La Prehistoria en el mundo. (traslated by Gonzáles, F.), Akal, Madrid, 752 p. (in Spanish) ("Prehistory in the world")

García- Franco, A. \& Morgado, A. 2016. Estudio tecnológico de un conjunto laminar Magdaleniense de la Subbética, abrigo 3 de Tajos de Marchales. Manuscript submitted and accepted, ANTIQVITAS, 28: 7-20. (in Spanish) (Technological study of a laminar Magdalenian ensemble of the Subbética, shelter 3 of clashes of Marchales)

Gilez, F., Finlayson, C., Gutierrez, J., Santiago, A., Finlayson, G. 2001. Investigaciones arqueológicas en Gorham's cave (Gibraltar). Resultados preliminares de las campañas 1977 a 1999. Almoraima, 25: p. 49-64. (in Spanish) (“Archaeological investigations at Gorham's cave (Gibraltar). Preliminary results of the campaigns from 1977 to 1999”) URL: http://hdl.handle.net/11532/307407

Inizan, M., Reduron-Ballinger, M., Roche, H., Tixier, J. 1999. Technology and terminology of knapped stone. Vol. 5 (translated by Flébot-Augustins, Jehanne). Maison de l'Archéologie et de l'Ethnologie, Vol. 3. Cercle de Recherches et d'Etudes Préhistoriques, Nanterre, 191 p.

Inizan, M.L. \& Roche, H. 1980, Préhistoire de la pierre taillée I. Terminologie et technologie. Circle de Recherches et d'Études Préhistoriques, Valbonne, 200 p. (in French) ("Prehistory of knapping stone I. Terminology and technology")

Jordá, F. 1986. La ocupación más antigua de la cueva de Nerja. La Prehistoria de la cueva de Nerja (Málaga). Trabajos sobre la Cueva de Nerja, $n^{\circ}$ 1. Paleolítico y Epipaleolítico, Málaga: p. 195-204. (in Spamish) ("The oldest occupation of the cave of Nerja. The Prehistory of the cave of Nerja, Malaga”)

Jordá, F. 1987. Sobre los niveles del Paleolítico superior de la Cueva de Nerja (Málaga). In: Anuário Arqueológico de Andalucía/1986, Sumario I, (Junta de Andalucía) Consejería de Cultura, Sevilla-Madrid: p. 285-287 (in Spanish) (“On the upper Paleolithic levels of the Cueva de Nerja, Málaga”)

Jordá, J. Aura, E. \& Jordá, F. 1990. El límite Pleistoceno-Holoceno en el yacimiento de la Cueva de Nerja (Málaga). Geogaceta, 8: 102-104. (in Spanish) ("The PleistoceneHolocene boundary at the site of the Cueva de Nerja, Málaga”) 
Julien, M. 2002. La tecnología y la tipología. Del fósil director a la cadena operativa. In: $L a$ prehistoria en el Mundo. Nueva edición de "la prehistoria” de André Leroi-Gourhan (J. Garanger, ed.) Akal, Madrid, p. 145-172. (in Spanish) ("Technology and typology. From the fossil director to the operational chain”)

Laplace, G. 1972. La typologie analytique?, L'Anthropologie, 70(1-2): 180-193. (in French) ("The analytical typology?”)

Merino, J. 1994, Tipología lítica ( $3^{a}$ edición corregida y aumentada). Munibe. AntropologiaArkeologia, suplemento Vol. 9. Sociedad de Ciencias Aranzadi, San Sebastian, 562 p. (in Spanish) ("Lithic typology (3rd ed. - corrected and augmented)")

Moure, J. 1970.Sobre la denominación en lengua castellana de los útiles del Paleolítico Superior de acuerdo con el sistema Sonneville-Bordes y Perrot. In: XI Congreso Nacional de Arqueología (Universidad de Zaragoza), Secretaría General de los Congresos Arqueológicos Nacionales, Mérida: p. 132-138. (in Spanish) (“The denomination in Castilian language of the tools of the Upper Paleolithic according to the system Sonneville-Bordes and Perrot”)

Pelegrin, J. 1990. Prehistoric lithic technology: Some aspects of research. Archaeological Review from Cambridge, 9(1): 116-125.

Pelegrin, J. 1991. Aspects de démarche expérimentale en technologie lithique. 25 ans d'etudes technologiques en Préhistoire. In: XI Rencontres Internationales d'Archéologie et d'Histoire d'antibes, Editions APDCA, C.R.A., Juan-Les-Pins, p. 57-63.

Pellicer, M. \& Acosta, P. 1997. El Neolítico y Calcolítico de la Cueva de Nerja en el contexto andaluz. In: Trabajos sobre la Cueva de Nerja, $n^{\circ}$ 6, Málaga: p. 225-350. (in Spanish) ("The Neolithic and Chalcolithic of the Cave of Nerja in the Andalusian context")

Pellicer, M. \& Morales, A. (Eds). 1995. La Fauna Holocena de la Cueva de Nerja. Trabajos sobre la Cueva de Nerja, Vol. 5 (Pellicer, M. \& Morales, A., Eds.), Fundación Cueva de Nerja, Málaga: p. 270-300. (in Spanish) (“The Holocene Fauna of the Nerja Cave”)

Perlés, C. 1987. Les industries lithiques taillées de Franchthi (Argolide, Grèce). Vol. 3. Excavations at Franchthi Cave, Greece, Vol. 13. Indiana University Press, Bloomington, 333 p. (in French) ("The lithic carved industries of Franchthi, Argolis, Greece”)

Perlés, C. 1991. Économie des matières premières et économie du débitage: Deux conceptions opposées. In: 25 ans d'études technologiques en Préhistoire: Bilan et perspectives, Editions APDCA, C.R.A., Antibes. p. 35-45. (in French) ("Economics of raw materials and economics of debitage: Two opposing conceptions”)

Ripoll, S. 1988. El Solutrense de la Cueva de Ambrosio (Vélez Blanco, Almería) y su posición cronoestratigráfica en el Mediterráneo Occidental. BAR International Series, Vol. 462,1, British Archaeological Reports, Oxford, 462 p. (in Spanish) (“The Solutrense of the Cave of Ambrosio (Vélez Blanco, Almería) and its chronostratigraphic position in the Western Mediterranean”)

Sackett, J. 1966. Quantitative Analysis of Upper Paleolithic Stone Tools, American Antrhopologist, 68(2): 326-394. doi:10.1525/aa.1966.68.2.02a001060

Sonneville-Bordes, D., Perrot, J. 1954. Lexique typologique du Paléolithique Supérieur. Bulletin de la Société Préhistorique Française, 51: 408-412. (in French) (“Glosario tipológico del Paleolítico Superior”) 
Toro, I. \& Almohalla, M. 1979. Industrias del paleolítico superior en Granada. Cuadernos de prehistoria y arqueología de la Universidad de Granada, 4: 1-20. (in Spanish) (“Upper Paleolithic Industries in Granada")

URL: http://revistaseug.ugr.es/index.php/cpag/article/view/807

Toro, I., Argamasilla, M., \& Almohalla, M. 1980. Nuevas aportaciones del Paleolítico superior en la provincia de Granada. Cuadernos de prehistoria y arqueología de la Universidad de Granada, 5: 1-14. (in Spanish) ("New contributions of the Upper Palaeolithic in the province of Granada”)

URL: http://revistaseug.ugr.es/index.php/cpag/article/view/946

Vallespí, E. 1995. Paleolítico y Epipaleolítico, In: Prehistoria de Andalucía. In: Actas del II Congreso Internacional El Estrecho de Gibraltar (Ripoll, E. \& Laredo, M., Eds.), Universidad Nacional de Educación a Distancia UNED, Madrid, 1, p. 45-67 (in Spanish) ("Paleolítico and Epipaleolítico, In: Prehistory of Andalusia”)

Vega, L. 2005. El final del Paleolítico Medio y el início del Paleolítico Superior: Más allá de los datos cantábricos. In: Neandertales cantábricos, estado de la cuestión. Actas de la reunión científica: Celebrada en el Museo de Altamira (Lasheras, J. \& Montes, M., Eds.), Ministerio de Cultura, Subdirección General de Publicaciones, Información y Documentación, Madrid: p. 541-556. (in Spanish) ("The end of the Middle Paleolithic and the beginning of the Upper Paleolithic: Beyond the Cantabrian data")

URL: https://dialnet.unirioja.es/servlet/articulo?codigo=5574568

Villaverde, V. \& Martínez, R. 1995. Características culturales y económicas del final del paleolítico superior en el Mediterráneo Español. In: Los últimos cazadores. Transformaciones culturales y económicas durante el Tardiglaciar y el inicio del Holoceno en el ámbito mediterrâneo (Villaverde, V., Ed.), Diputación Provincial de Alicante, Valencia: p. 79-118. (in Spanish) ("Cultural and economic characteristics of the Late Paleolithic in the Mediterranean Spanish”)

Villaverde, V., Martínez, R., Badal, E., Gillem, P., García, R. \& Menargues, J. 1999. El Paleolítico Superior de la Cova de Les Cendres (Teulada-Moraima, Alicante). Datos proporcionados por el sondeo efectuado en los cuadros A/B-17. Archivo de Prehistoria Levantina, 23: 9-65. (in Spanish) ("The Upper Paleolithic of the Cave of Les Cendres (Teulada-Moraima, Alicante). Data provided by the survey carried out in Tables A / B17”) URL: http://hdl.handle.net/11441/32227

Villaverde, V., Martínez, R., Roman, R., Iborra, M., Pérez, M. 2008. El Gravetiense de la vertiente mediterránea ibérica: Reflexiones a partir de la secuencia de la Cova de Les Cendres (Moraira, Alicante). Veleia, 24-25: 445-468. (in Spanish) (“The Gravettian of the Iberian Mediterranean slope: Reflections from the sequence of the Cova de Les Cendres ,Moraira, Alicante”) URL: http://www.ehu.eus/ojs/index.php/Veleia/article/view/2017

Villaverde, V.; Aura, J. \& Barton, M. 1998, The Upper Paleolithic in Mediterranean Spain: A review of current evidence. Journal of World Prehistory, 12(2): 121-198. doi:10.1023/A:1022332217614

Zilhão, J. (1997): O Paleolítico Superior da Estremadura portuguesa. Vol.1. Edições Colibri, Lisbon, 309 p. (in Portuguese) ("The Upper Palaeolithic in the Portuguese Extremadura”) 